\title{
The Announcement Effects of Convertible Bond Issuances and Refixing Conversion Prices
}

\author{
Pyung Sig Yoon", Professor, Chungnam National University
}

\begin{abstract}
$\langle$ Abstract $\rangle$
Using a sample of 1,421 convertible bond (CB) issuances announced between 2015 and 2018, this study examines the announcement effects of convertible bond issuances and refixing conversion prices (i.e., adjusting conversion price downward if stock price decreases after issuance). The major results are as follows: First, the announcement effect of CB issuances is significantly positive and the three-day cumulative abnormal return is $4.66 \%$. Second, the announcement effect of $\mathrm{CB}$ issuances stating capital expenditures as the use of proceeds is significantly smaller than that of $\mathrm{CB}$ issuances stating other purposes. Third, the fact that the announcement effect of $\mathrm{CB}$ issuances with a refixing option is significantly smaller than that of those without a refixing option reflects the stock market's negative opinion of the refixing option. Fourth, consistent with the third result, the announcement effect of refixing is also significantly negative. To summarize, this study contributes to finance theory by presenting, for the first time, evidence to support the negative effects of refixing options that are extremely favorable to holders.
\end{abstract}

Keywords: Convertible Bond; Announcement Effect; Conversion Price Adjustment; Refixing; Private Placement

JEL Classification: G14, G32, G38

* Corresponding Author. Address: Chungnam National University, School of Business, 99 Daehak-ro, Yuseong-gu, Daejeon, Korea 34134; E-mail: psyoon@cnu.ac.kr; Tel: +82-42-821-5540; +82-42-821-8718.

Received: September 10, 2019; Revised: December 26, 2019; Accepted: January 13, 2020 


\title{
전환사채발행과 리픽싱의 공시효과에 관한 연구
}

\author{
윤 평 식 (충남대학교 교수)*
}

\begin{abstract}
본 연구는 2015년부터 2018년까지의 전환사채 발행표본 1,421건을 구성하여 전환사채발행과 전환가액 조정(리픽싱)의 공시효과를 검증한다. 리픽싱은 발행후 주가가 하락하면 전환가격을 하향조정하는 것을 의미한다. 본 연구의 주요 결과를 요약하면 다음과 같다. 첫째, 전환사채발행 공시효과는 양(+)으로 유의적이며 공시일을 전후한 3일간 누적초과수익률은 $4.66 \%$ 이다. 둘째, 시설자금조달을 목적으로 공시한 전환사채발행의 공시효과가 다른 목적의 공시효과보다 유의적으로 작다. 셋째, 리픽싱옵션이 포함된 경우의 전환사채발행 공시효과가 리픽싱옵션이 제외된 경우의 공시효과보다 유의적으로 작은데, 이는 리픽싱옵션에 대한 부정적인 견해를 반영한다. 넷째, 세 번째 결과와 일관성있게 리픽싱옵션에 의한 전환가액조정 공시효과도 음(-)으로 유의적이다. 요약하면, 리픽싱옵션은 투자자에게 지나치게 유리한 조항으로 간주되는데 본 연구는 리픽싱옵션의 부정적 효과를 지지하는 실증증거를 최초로 제시한다는 점에서 재무이론에 공헌한다.
\end{abstract}

핵심 단어 : 전환사채, 공시효과, 전환가액조정, 리픽싱, 사모

JEL 분류기호: G14, G32, G38

* 연락담당 저자. 주소: 대전광역시 유성구 대학로 99, 충남대학교 경상대학 경영학부, 34134 ; E-mail: psyoon@cnu.ac.kr; Tel: 042-821-5540; Fax: 042-821-8718. 


\section{1. 서론}

기업은 자본적 지출과 운영에 필요한 자금을 주식, 회사채, 메자닌 상품 등의 발행을 통하여 조달한다. 메자닌(mezzanine) 상품은 주식과 채권의 성격을 모두 포함하는 상품으로, 국내에서 매우 활발하게 이용되고 있는 대표적인 상품이 전환사채(convertible bond: $\mathrm{CB}$ )와 신주인수권 부사채(bond with warrant: BW)이다. 신주인수권부사채는 분리형 사모(private placement)의 형태로 2010년 이후 매우 활발하게 발행되었으나 여러 문제점(대주주 지분 확대, 재산증여, 대주주 이익추구, 시세조정, 기존주주 지분율 희석 등)이 노출되어 2013년 8월 이후 지금까지 분리형 사모 $\mathrm{BW}$ 의 발행은 금지되고 있다. 분리형 사모 $\mathrm{BW}$ 가 금지됨에 따라 상장기업(특히 코스닥기업)은 사모 전환사채를 이용하여 활발하게 자금을 조달하고 있다.

전환사채는 1963년에 최초로 발행되었으며 이후 상장기업의 자금조달 창구로서의 역할을 꾸준히 수행하고 있다. 물론 전환사채를 통한 자금조달 금액은 시장상황과 정부의 정책 등에 의해 등락이 심하다. Byun and Park(2017)과 본 연구의 표본에 기초하여 2000년 이후만 살펴보면 전환사채는 2006년부터 2009년까지 그리고 2014년부터 현재까지 매우 활발하게 발행되고 있다(2009년부터 2013년까지는 신주인수권부사채의 발행이 매우 큼). 예를 들어, 2018년의 경우 489건의 전환사채 발행으로 6.65 조 원이 조달되었다.1) 특히 정부의 모험자본 육성정책에 힘입어 벤처펀드와 사모펀드의 규모가 커지면서 최근 $\mathrm{CB}$ 발행이 폭발적으로 성장하고 있다. 문제는 코스닥시장 규모와 비교할 때 $\mathrm{CB}$ 발행규모가 너무 빠르게 성장하고 있어 소액주주의 피해가 우려되고 있는 상황이다. 2015년 금융위가 자본시장법을 개정해 헤지펀드 운용업 진입규제를 인가제에서 등록제로 완화하고 최소 자기자본 기준도 60 억 원에서 20 억 원으로 낮춤에 따라, 2018년 5월 기준으로 헤지펀드 운용사는 136 개, 운용자산은 32 조 원에 이른다. 특히 2018년에는 $\mathrm{CB}$ 와 BW 등의 메자닌채권을 주요 운용자산으로 하는 코스닥벤처펀드까지 도입되면서 발행규모의 성장 속도가 더욱 가속화되고 있다. 코스닥벤처펀드는 전체 자산의 $15 \%$ 를 벤처기업 신주에 투자해야 하는데 $\mathrm{CB}$ 와 $\mathrm{BW}$ 등이 신주의무투자비율을 충족시키는 데 유리하게 작용하면서 메자닌채권 발행이 급증했다. 미국과 유럽의 경우 $\mathrm{CB}$ 발행규모가 최근 감소한 반면 우리나라에서는 반대로 폭발적으로 성장하고 있다. 미국 상장회사의 $\mathrm{CB}$ 발행액이 주식시장의 시가총액에서 차지하는 비중은 대략 $0.15 \%$ 로 알려져 있는 반면, 우리나라 코스닥의 $\mathrm{CB}$ 발행규모는 코스닥 시가총액의 $2 \%$ 를 웃도는 것으로 추정된다. ${ }^{2)}$

전환사채는 신용등급이 낮지만 부채비율이 높고 성장성이 좋은 신생기업이 주로 활용하는 자금조달수단으로 인식되고 있다(Eom and Cho, 2017). 전환사채를 발행하는 이유로는 이자비용 절감, 위험평가오류로부터 투자자 보호, 대리인비용 감소, 잠재적 자기자본(backdoor equity)의 역할 등이 주로 언급된다. Oh and $\operatorname{Kim}(2013)$ 은 부채의 대리인비용 감소, 유상증자에서 발생하는

1) 본 연구의 표본을 이용하여 계산하였으며 최초공시자료를 활용하며 같은 날에 2건 이상이 발행된 경우 한 건으로 통합하였다. 이 자료는 최초공시자료만을 이용하였으므로 실제로 조달된 금액과 약간 차이가 있을 것으로 예상한다.

2) 한국경제신문, “헤지펀드, 큰손, 상장사 ‘전환사채 커넥션' ... 소액주주만 전전긍긍”, 2018년 5월 23일자. 
The Announcement Effects of Convertible Bond Issuances and Refixing Conversion Prices

정보비대칭 비용의 감소, 위험회피 등을 전환사채 발행 이유로 요약한다(Green, 1984; Brennan and Schwartz, 1988; Mayers, 1998; Stein, 1992; Lewis et al., 2003). Green(1984)은 전환사채가 채권자의 결정에 의해 자기자본으로 전환이 가능하므로 부채의 대리인비용(agency cost of debt)을 감소시킬 수 있다고 주장한다. Mayers(1998)는 전환사채 발행이 자금조달비용을 절약함과 동시에 과잉투자문제(overinvestment problem)를 해결할 수 있다고 주장한다. Brennan and Schwartz(1998)는 전환사채의 가치가 발행기업의 위험에 따라 민감하게 반응하지 않으므로 전환사채 발행이 발행기업의 위험을 줄일 수 있다고 주장한다. Stein(1992)은 유상증자를 실시하면 주가가 크게 하락하는데 이를 피하기 위하여 이미 부채수준이 높은 기업이 잠재적 자기자본인 전환사채를 발행한다고 주장한다. Lewis et al.(2003)는 상당한 크기의 정보비대칭과 재무곤경비용에 직면한 기업이 유상증자로 인해 발생하는 비용을 줄이기 위하여 전환사채를 발행한다고 주장한다.

그리고 증권이 사모로 발행되는 경우 외부투자자가 발행기업에 대하여 감시활동을 함으로써 대리인비용을 감소시키고 기업가치를 증가시킬 수 있는데 이 모니터링가설(monitoring hypothesis)은 제 3 자배정 유상증자의 양의 유의적인 공시효과를 설명하는데 주로 이용된다(Shleifer and Vishny, 1986; Wruck, 1989). 또한 정보비대칭 측면의 보증 가설(certification hypothesis)에 의하면 사모발행 참여자는 주로 정보거래자(informed trader)이므로 그들의 참여는 현재의 저평가된 기업가치를 확증할 수 있다고 주장한다(Hertzel and Smith, 1993).

우리나라에서 전환사채에 관한 기존 연구는 공시효과, 발행기업의 특성, 전환사채차익거래, 전환사채 규정과 법적 문제점 등에 집중되어 있다. 특히 전환사채 발행에 따른 공시효과는 여러 논문에서 검증되었으나 결과가 비유의적이거나(Kwon et al., 1992; Kho and Park, 2000; Jung and Cha, 2009), 양(+)으로 유의적이거나(Yun and Jeong, 2001; Park and Baek, 2003; Oh and Kim, 2013; Kim and Han, 2019), 음(-)으로 유의적으로(Woo, 1995; Kwak, 2012; Byun and Park, 2017) 나타나는 등 혼재되어 있다. 이와는 달리, 미국과 영국의 경우 전환사채는 유의적인 음의 공시효과를 야기하는 것으로 보고된다(Eckbo, 1986; Abhyankar and Dunning, 1999; Duca et al., 2012). 한편, Kang and Stulz(1996)는 일본 공모발행 전환사채 561건의 공시효과를 분석한 결과 공시일 전후 3 일간의 누적초과수익률이 $1.05 \%$ 이고 $1 \%$ 신뢰수준에서 유의적이라고 보고한다. 그리고 호주와 프랑스의 경우 공시효과가 유의적인 음이고 네덜란드의 경우 유의적인 양이다(Loncarski et al., 2006).

전환사채 및 신주인수권부사채와 관련하여 최근에 제기된 이슈가 투자자에게 지나치게 유리한 리픽싱옵션(refixing option) 또는 리픽싱조항(refixing clause)의 혜택이다. 리픽싱은 발행 후 주식가격이 하락하면 전환가격 또는 행사가격을 하향조정하는(일반적으로 최초행사가격의 $70 \%$ 까지) 것을 의미한다(주가가 상승하더라도 상향조정되지는 않음). 국내에서 발행되는 전환사채와 신주인수권부사채의 리픽싱조항은 1999년 말에 기업이 $\mathrm{CB}$ 와 $\mathrm{BW}$ 를 통해 쉽게 자금을 조달할 수 있도록 하기 위한 목적으로 도입되었다.3) 전환사채의 경우 리픽싱조항이

3) 국내에서 발행되는 $\mathrm{CB}$ 와 $\mathrm{BW}$ 의 경우 리픽싱옵션이 최초로 부여된 것은 1999 년 10 월 현대전자(현재의 $\mathrm{SK}$ 하이닉스)가 발행한 $\mathrm{BW}$ 이다. 
한국증권학회지 제49권 2호 (2020)

포함되면 발행이 용이해지고 전환 가능성이 증가하여 부채가 자본으로 전환되는 것이 보다 확실해지는 효과도 있다. 전환사채는 원래 발행 후 주가가 상승하면 투자자가 주식으로 전환하여 이익을 얻는 구조이다. 그런데 리픽싱조항이 포함되면 원래의 이익구조가 변형되어 발행 후 주가가 많이 하락하더라도 리픽싱이 이루어진 후 주가가 상승하면 투자자는 이익을 얻을 수 있게 된다. 따라서 발행 후 주가가 하락하면 투자자는 더 많은 시세차익의 기회를 갖게 되지만 주주는 손해를 보게 되므로 투자자와 주주간의 이해관계가 상충되며, 이런 구조에서 주가를 인위적으로 조정하려는 유인이 발생할 수 있다(Kim, 2001; Lee, 2009; Kang, 2016). 또한 전환가격이 하락하면 전환주식수가 증가하므로(예를 들어 전환가격이 $70 \%$ 로 하향조정되면 전환주식수는 $1 / 0.7=1.43$ 배로 증가함) 투자자가 낮은 가격으로 보다 많은 주식을 보유하게 되어 기존주주 입장에서는 상당한 주가희석화가 불가피하게 발생한다. 상법 및 자본시장법은 $\mathrm{CB}$ 와 $\mathrm{BW}$ 의 발행에 대하여 여러 제약규정을 두고 있지만 리픽싱조항은 자금조달이라는 원래의 취지를 벗어나 대주주가 이를 악용하도록 유도하는 역할을 하게 된다(Solidarity for Economic Reform, 2010; Kang, 2016).

Yoon(2015a)과 Yoon(2019)은 신주인수권부사채를 대상으로 리픽싱옵션의 문제점을 제기 한다. Yoon(2019)은 사모 분리형 신주인수권부사채 발행 중에서 최대주주 등의 특수관계인이 사채권자로부터 신주인수권을 매입(환매)한 249건을 대상으로 분석한 결과, 최대주주 등이 실제로 얻은 수익률이 평균 1,441\%이며 대략 절반에 해당되는 $674 \%$ 포인트는 리픽싱옵션으로 인한 혜택이고 나머지는 터무니없이 낮은 신주인수권의 가격에 기인한다고 보고한다. Byun and Park(2017)도 리픽싱옵션은 투자자에게 지나치게 유리한 조항이므로 폐지되어야 한다고 주장한다.

본 연구에서 검증하고자 하는 내용은 다음의 두 가지이다. 첫째, 전환사채 발행의 공시효과를 검증하는 것이다. 기존의 연구결과가 세 가지로 혼재되어 있는데 본 연구는 발행량이 폭발적으로 성장한 최근 4년을 연구대상으로 대규모 표본을 구성하고 공시효과를 분석하기로 한다. 최근에 발행된 전환사채의 특성은 사모 발행이고 리픽싱옵션이 첨부되어 있다는 점이다. 또한 사모펀드의 성장, 코스닥벤처펀드의 $\mathrm{CB}$ 와 $\mathrm{BW}$ 의무보유 규정 등으로 인해 발행자 중심의 시장이 형성됨에 따라 전환사채의 표면이자율과 만기이자율이 상당히 낮게 설정되어 발행된다.4) 둘째, 리픽싱 옵션은 투자자에게 지나치게 유리한 조항이므로 전환사채 발행 후 리픽싱이 이루어지면 전환 가격이 하락하게 되고 이로 인해 사채권자는 헐값에 신주를 매입하게 되므로 리픽싱(전환가액 하향조정)은 부정적인 정보를 시장에 전달할 것으로 예상된다. 본 연구는 리픽싱옵션의 유무가 공시효과에 미치는 영향뿐만 아니라 전환가액조정의 공시효과를 직접 분석하여 실제로 부정적인 정보가 시장에 전달되는지 확인하고자 한다.

본 연구는 전환사채가 가장 활발하게 발행된 2015년부터 2018년까지의 4년을 연구기간으로 설정하고, 전환사채발행 1,421 건을 기본 연구표본으로 구성하여 전환사채 공시효과를 분석한다. 그리고 1,421 건을 발행한 529 개 기업을 대상으로 전환가액조정공시 1,798 건의 표본을 구성하고

4) 본 연구표본 1,421 건 중에서 표면이자율이 $0 \%$ 인 경우는 $49 \%$ 인 701 건이고, 만기수익률이 $0 \%$ 인 경우는 $14 \%$ 인 196 건이다. 
The Announcement Effects of Convertible Bond Issuances and Refixing Conversion Prices

전환가액조정의 공시효과도 분석한다. 앞에서 언급했듯이, 이 연구기간에 발행된 전환사채는 전적으로 사모 중심으로 발행되며 리픽싱옵션의 채택비율도 $95.4 \%$ 로 매우 높다.5) 우리의 표본에서 리픽싱 또는 전환가액 조정은 $64 \%$ 의 경우 $70 \%$ 까지 허용되고( $29 \%$ 의 경우 액면가까지 허용되고) $66 \%$ 의 경우 매 3 개월마다( $30 \%$ 의 경우 매 1 개월마다) 이루어진다.

본 연구의 주요 결과를 요약하면 다음과 같다. 첫째, 전환사채발행 공시효과는 양으로 유의적이다. 가장 큰 주가변화는 공시일 전일에 발생하는데 초과수익률은 $2.87 \%$ 이고 t-value는 14.50 이다. 그리고 공시일의 초과수익률은 $1.22 \%$ 이고 t-value는 6.26 이다. 공시일 전에 $\mathrm{CB}$ 발행 정보가 노출된 것으로 판단되며, 공시일을 전후하여 3일, 5 일, 7 일간의 $\mathrm{CAR}$ 가 각각 $4.66 \%, 5.83 \%, 6.30 \%$ 이다. 둘째, 자금조달 목적으로 구분하여 분석한 결과, 시설자금목적으로 전환사채를 발행하면 공시효과는 전혀 유의적이지 않고, 이는 운영자금목적 또는 타법인증권취득자금목적의 공시효과보다 유의적 으로 작다. 셋째, 리픽싱옵션이 포함된 경우의 $\mathrm{CB}$ 발행 공시효과가 리픽싱옵션이 제외된 경우의 공시효과보다 유의적으로 작은데 이는 리픽싱옵션에 대한 부정적인 견해를 반영한다.

넷째, 리픽싱옵션의 유무가 공시효과에 영향을 미치는 세 번째 결과와 일관성 있게, 전환가액 조정 공시효과도 음으로 유의적이다. 공시일에 초과수익률은 $-0.27 \%$ 이고 t-value는 -3.16 이다. 시장이 전환가액조정 공시에 대해 부정적으로 반응하는 것은 투자자에게 지나치게 유리한 리픽싱옵션으로 인해 전환가격이 하향조정되는 것이 기존주주의 부를 해친다는 견해를 반영하는 것이다.

본 연구는 공헌도는 다음과 같다. 첫째, 전환사채발행의 공시효과를 재검증하면서 양의 유의적인 초과수익률을 발견하였을 뿐만 아니라 리픽싱옵션이 포함된 전환사채의 공시효과가 옵션이 제외된 전환사채의 공시효과보다 유의적으로 작음을 보고한다. 이는 리픽싱옵션의 존재가 결국 공시효과를 하락시키는 부정적인 요소임을 의미한다. 둘째, 리픽싱옵션이 부여되면 초과 수익률이 상대적으로 작다는 결과와 일관성있게, 발행기업이 리픽싱옵션에 의해 전환가액이 하항조정된다고 공시하면 공시일에 주가가 유의적으로 하락한다는 결과를 최초로 보고한다.

본 논문의 구성은 다음과 같다. 먼저 제 2장에서 선행연구를 요약하고, 제 3장에서 표본구성, 방법론, 검증가설을 소개하기로 한다. 실증 결과는 제 4 장에 제시되어 있으며 제 5 장에서 결론을 도출하기로 한다.

\section{2. 기존연구 요약}

\section{1 전환사채발행 공시효과에 관한 기존연구 요약}

전환사채에 대한 공시효과는 여러 논문에서 연구되었으며 주요 논문의 결과를 요약하면 <표 $1>$ 과 같다. 국내 전환사채 발행에 대한 공시효과는 비유의적, 양으로 유의적, 음으로 유의적

5) 4 년 동안 공모로 발행된 건은 17 건인데 본 연구의 사모 전환사채 표본이 1,421 건이므로 공모발행비율은 $1.2 \%$ 에 지나지 않는다. 반면에 Park and Baek(2003)은 1987년부터 1999년까지 898건의 표본을 구성하였는데 $80 \%$ 가 공모발행인 점으로 미루어 예전에는 공모발행이 사모발행보다 많았던 것으로 추정된다. 또한 뒤에 언급되어 있지만 리픽싱옵션이 포함되지 않은 경우는 66 건으로 $4.6 \%$ 에 해당된다. 
한국증권학회지 제49권 2호 (2020)

등으로 나타나 연구결과가 매우 불명확하다. Kwon et al.(1992), Kho and Park(2000), Jung and Cha(2009)는 비유의적인 결과를 보고한다. 처음 두 논문은 표본기간이 오래되었고 세 번째 논문은 비교적 최근 자료를 이용하지만 표본수가 매우 작다.

〈표 1〉 전환사채 공시효과에 관한 기존연구 결과 요약

이 표는 전환사채 공시효과에 대한 기존연구를 표본기간, 표본수, 초과수익률을 기준으로 정리한 표이다. $\mathrm{AR}$ 은 초과수익률을, $\mathrm{CAR}$ 은 누적초과수익률을, 그리고 0은 공시일을 의미한다. *, **, ***는 각각 $10 \%$, $5 \%, 1 \%$ 수준에서 통계적으로 유의함을 의미한다.

\begin{tabular}{|c|c|c|c|c|}
\hline 논문 & 결과 & 표본기간 & 표본수 & 공시효과 \\
\hline Woo(1995) & (-) 유의적 & $1987 \sim 1993$ & 121 & $\operatorname{CAR}(0,1)=-0.204 \%(* * *)$ \\
\hline Kwon et al.(1992) & (-) 비유의적 & $1987 \sim 1991$ & 145 & $\mathrm{AR} 0=-0.094 \%$ \\
\hline Kho and Park(2000) & (+) 비유의적 & $1981 \sim 1995$ & 422 & $\operatorname{CAR}(-10,10)=0.15 \%$ \\
\hline Yun and Jeong(2001) & (+) 유의적 & $1987 \sim 1998$ & 295 & $\begin{array}{c}\mathrm{ARO}=0.29 \%(*) \\
\text { 공모로 제한 }\end{array}$ \\
\hline Park and Baek(2003) & (+) 유의적 & 1987 1999 & 898 & $\begin{array}{c}\mathrm{CAR}(-1,1)=0.55 \%(* *) \\
\text { 표본의 } 80 \% \text { 가 공모임 }\end{array}$ \\
\hline Jung and Cha(2009) & (+) 비유의적 & $2000 \sim 2008$ & 47 & $\operatorname{CAR}(-1,1)=0.749 \%$ \\
\hline $\operatorname{Kwak}(2012)$ & (-) 유의적 & $2001 \sim 2009$ & 236 & $\begin{array}{l}\mathrm{CAR}(0,1)=-0.58 \%(* *) \\
\text { 유가증권시장으로 제한 }\end{array}$ \\
\hline Oh and $\operatorname{Kim}(2013)$ & (+) 유의적 & $2000 \sim 2011$ & 822 & $\operatorname{CAR}(-1,1)=1.87 \%(* * *)$ \\
\hline Byun and Park(2017) & (-) 유의적 & $2000 \sim 2015$ & 813 & $\operatorname{CAR}(-3,3)=-1.05 \%(* *)$ \\
\hline Kim and Han(2019) & (+) 유의적 & $2000 \sim 2015$ & 1,508 & $\operatorname{CAR}(-1,1)=1.45 \%(* * *)$ \\
\hline
\end{tabular}

Yun and Jeong(2001), Park and Baek(2003)은 주로 90년대의 공모발행을 주요 대상으로 분석하였으며 유의적인 양(+)의 공시효과를 보고한다. 그리고 Oh and $\mathrm{Kim}(2013)$ 은 2000년부터 2011년까지 공시된 전환사채 표본 822건을 대상으로 공시효과를 분석한 결과, 공시일을 전후한 3 일간의 누적초과수익률이 $1.87 \%$ 라고 보고한다 (t-value $=4.80)$. 또한 표본기간을 2000 2007년과 2008 2011년으로 구분한 결과, 전반기의 누적초과수익률이 $1.5 \%$ 인 반면 하반기의 누적초과 수익률은 2.6\%라고 보고하여 공시효과가 커지고 있음을 보여준다. 그리고 Kim and Han(2019)은 2000년부터 2015년까지 공시된 전환사채 표본 1,508 건을 분석한 결과 공시일을 전후한 3 일간 누적초과수익률이 $1.45 \%$ 로 $1 \%$ 신뢰수준에서 유의적이며, 시설자금조달을 목적으로 공시하는 $\mathrm{CB}$ 의 공시효과가 다른 목적의 공시효과보다 유의적으로 크다고 보고한다.

반면에 Woo(1995), Kwak(2012), Byun and Park(2017)은 유의적인 음(-)의 공시효과를 보고한다. Woo(1995)의 연구는 매우 오래전에 이루어졌지만, 남은 두 연구는 비교적 최근의 연구이고 표본 수도 그리 작지 않다. Kwak(2012)은 2001년부터 2009년까지 유가증권시장 전환사채발행 공시효과를 분석한 결과 이틀 누적초과수익률이 $-0.58 \%$ 이며 이는 $5 \%$ 신뢰수준에서 유의적이라고 한다. 그리고 Byun and Park(2017)은 2000년부터 2015년까지 813건을 대상으로 공시효과를 분석한 결과 공시일 전후 7 일간의 누적초과수익률이 $-1.05 \%$ 이며 $5 \%$ 신뢰수준에서 유의적이라고 보고한다.

전환사채 발행이 레버리지를 증가시키는 자금조달이므로 양의 공시효과가 예상되기도 하지만, 
The Announcement Effects of Convertible Bond Issuances and Refixing Conversion Prices

대부분의 전환사채가 궁극적으로 주식으로 전환된다는 측면에서(특히 리픽싱옵션이 추가된 경우 전환될 가능성은 더욱 증가함) 음의 공시효과가 예상되기도 한다(Park and Baek, 2003).

우리나라에서 이처럼 상이한 실증결과가 혼재하는 상황에서 본 연구는 최근의 자료를 대상으로 대규모 표본을 구성하여 공시효과를 분석하기로 한다. 한편, 전환사채와 유사한 신주인수권 부사채의 경우, Yoon(2015b)은 2009년 7월부터 2012년 말까지 공시된 BW를 대상으로 554건의 표본을 구성하고 공시효과를 분석한 결과, 유의적인 양의 초과수익률을 보고하는데 이는 비환매 기업에만 적용된다고 보고한다(여기서 비환매기업이란 $\mathrm{BW}$ 발행과 동시에 최대주주 등의 특수 관계인과 제3자가 신주인수권을 매입하지 않는 기업임). 한편 Oh and $\mathrm{Kim}(2013)$ 은 900여 건의 분리형 신주인수권부사채 발행의 공시효과를 분석하였으며 공시일 전후 3 일간의 누적초과 수익률을 1.87\%로 보고한다. 그리고 Yoon(2019)은 최대주주가 신주인수권부사채에 부가된 신주인수권을 매입(환매)한 경우 신주인수권부사채 발행의 공시효과가 음으로 유의적이라고 보고한다(공시일 초과수익률은 $-0.92 \%$ 이고 t-value는 -3.07 임).

\section{2 리픽싱옵션에 관한 기존연구 요약}

리픽싱옵션(refixing option)은 우리나라의 경우 전환사채와 신주인수권부사채 발행에 첨가되어 발행되며, 발행 후 주식가격이 하락하면 일정한 간격으로 최초의 전환가격 또는 행사가격 이하로 (일반적으로 $70 \%$ 까지) 전환가격 또는 행사가격을 하향조정할 수 있는 옵션이다(주가가 상승하더라도 상향조정되지는 않음). Byun and Park(2017)은 전환사채를 대상으로 리픽싱옵션 채택비율을 연도별로 분석하였으며, 2001년 2003년의 경우 리픽싱옵션 채택비율이 $50 ~ 60 \%$ 대였으나, 이후 점진적으로 증가하여 2010년 2015년의 경우 94 97\%대라고 보고한다(2013년은 84\%임). Yoon(2019)은 신주인수권부사채 연구표본 249건 모두에서 리픽싱옵션이 적용된다고 한다. 이상의 연구는 최근에 발행된 $\mathrm{CB}$ 와 $\mathrm{BW}$ 는 거의 예외없이 리픽싱옵션을 포함한다는 것을 보여준다.

리픽싱옵션은 주요 선진국 중에서 우리나라와 일본에서 활발하게 이용되는 조항이다. 일본의 경우 리픽싱옵션은 신주인수권부사채에는 적용되지 않고 전환사채에서 활발히 이용된다(이를 일본에서는 Moving Strike Convertible Bond(MSCB) 또는 전환가격수정조항부전환사채 (轉換價格修正條項附轉換社債)로 부름(Byun and Park, 2017)). 미국의 경우 일부 기업에 한해 사모에서 제한적으로 사용되는데 이를 death spiral convertible bond, toxic convertible bond, floating price convertible bond 등으로 불린다.6) 반면에 우리나라의 경우 전환사채와 신주인수권 부사채 모두에서 활발하게 이용되며 이로 인해 여러 문제점이 야기된 것도 사실이다. Yoon(2019)은

6) Hillion and Vermaelen(2004)은 1994년 1월부터 1998년 6월까지 261개 기업이 발행한 467건의 death spiral convertible을 분석한 결과, 공시월부터 1년 동안의 누적초과수익률이 $-30 \%$ 이라고 보고한다. Hoffer(2010)는 1990년대 후반 이후 death spiral convertible의 인기가 하락하는데 이유는 헤지펀드의 성장으로 인한 금융시장의 변화, 미국증권거래위원회(SEC)의 감독 강화, 그리고 death spiral convertible의 위험성에 대한 인식 제고 때문이라고 한다. Dwyer et al.(2018)은 2010년부터 2016년 까지를 대상으로 death spiral convertible 발행 326건을 분석하였는데 발행기업은 30개에 지나지 않는다. 또한 ISMA(International Securities Market Association)의 자료에 의하면 일본 전환사채 발행 348건의 경우 리픽싱조항이 있는 경우가 193건인 데 반하여 미국 전환사채발행 119 건의 경우 리픽싱조항이 있는 경우는 단 1건이라고 보고한다(Yoon, 2015a). 
한국증권학회지 제49권 2호 (2020)

주요 국가에서 신주인수권부사채에 리픽싱옵션을 부여한 국가는 우리나라가 유일한데, 이유는 1999년 상장기업의 자금조달 애로를 해소하고자 리픽싱옵션을 한시적으로 허용하였고 이후 시장상황이 변함에도 불구하고 그대로 정착되었기 때문이라고 주장한다. 그는 리픽싱옵션은 투자자에게 지나치게 유리한 조항이므로 현실적인 대안으로 혜택을 축소하거나 차등 적용할 것을 제안한다. 그리고 리픽싱옵션이 적용되는 경우 전환가격이 하락하면 전환권의 가치가 상대적으로 증가하여 사채권자의 이익이 증가하기도 하지만 기업의 손실이 증가할 수도 있다.7)

리픽싱옵션에 관한 연구는 Yoon(2015a), Byun and Park(2017), Yoon(2019)에 의해 수행 되었다. Yoon(2015a)은 2009년 7월부터 2013년 8월 28일까지 공시된 신주인수권부사채 중에서 신주인수권이 최대주주 등에게 매각된 373건의 사모 분리형 $\mathrm{BW}$ 를 분석하였다. $\mathrm{BW}$ 는 발행 후 1 년이 지난 시점부터 행사가 가능한데 신주인수권만을 인수한 최대주주 등이 이 시점에서 행사한다고 가정하고 수익률을 계산한 결과, 1 년 동안 평균 $460 \%$ 의 수익률을 얻는 것으로 분석하였다. 이 연구에서 구한 수익률은 최대주주 등이 실제로 실현한 수익률이 아니라 일정한 가정하에서 계산된 가상의 수익률이다. 즉, 행사가 금지된 1년 동안 행사가격조정은 계속적으로 이루어지고 또한 최대주주는 행사가 가능한 첫날에 모두 행사한다는 가정이다. 놀랍게도 이 기간(발행 후 1 년) 동안 주식의 평균 수익률은 $-2 \%$ 인데 이렇게 주가가 하락하는 상황에서 최대주주 등이 평균 $460 \%$ 의 수익률을 얻을 수 있었던 이유는 레버리지효과와 리픽싱옵션 때문이라고 보고한다.

Byun and Park(2017)은 전환사채에 부가된 리픽싱옵션에 대하여 연구하였다. Byun and $\operatorname{Park}(2017)$ 은 리픽싱옵션이 부가된 전환사채의 공시효과가 리픽싱옵션이 부가되지 않은 전환사채의 공시효과보다 더 부정적이며,8) 행사가격조정이 이루어지는 날에 주가가 부정적으로 반응한다고 보고하며, 이 조항은 전환사채 투자자만을 지나치게 보호하는 조항이라고 주장하지만 결과 해석에 있어 자의적이고 비논리적인 부분이 많아 저자의 주장을 지지하는 실증증거가 제시되었다고 보기 어렵다.9)

7) 현재 한국채택 국제회계 기준(K-IFRS)에 의하면 전환사채의 전환권 대가는 부채 또는 자본으로 분류 가능하다. 만약 부채로 분류하는 경우 주가가 오르면 전환권 가치가 상승하고, 그 차액을 파생상품 손실로 회계처리하기 때문에 현금유출이 없음에도 기업의 손실이 발생할 수 있다(2019.01.29. 연합인포맥스, “전환사채 리픽싱 급증의 그늘 ... 가치희석에 파생손실까지”). 그러나 자본으로 분류하는 경우 손익이 발생하지 않는다.

8) 리픽싱옵션이 부가된 전환사채 $(\mathrm{CB}) 650$ 건과 리픽싱옵션이 부가되지 않은 $\mathrm{CB} 163$ 건을 분석한 결과, 리픽싱옵션이 부가된 $\mathrm{CB}$ 표본의 경우 $\mathrm{CAR}(-1,1)$ 은 전혀 유의적이지 않지만 $\mathrm{CAR}(-3,3)$ 과 $\mathrm{CAR}(-5$, $5)$ 는 각각 $-1.07 \%$ 와 $-2.77 \%$ 로 유의적이다. 반면에 리픽싱옵션이 첨부되지 않은 $\mathrm{CB}$ 의 경우 $\mathrm{CAR}(-1,1)$, $\operatorname{CAR}(-3,3), \operatorname{CAR}(-5,5)$ 가 모두 유의적이지 않다. 두 그룹 각각의 $\operatorname{CAR}(-1,1)$ 이 전혀 유의적이지 않고 두 그룹간 차이도 없는 상황에서, 리픽싱옵션 그룹의 $\operatorname{CAR}(-3,3)$ 과 $\operatorname{CAR}(-5,5)$ 가 유의적이지만 비리픽싱옵션 그룹의 $\mathrm{CAR}$ 는 유의적이지 않다는 결과만으로 공시효과에서 차이가 있다고 하는 것은 다소 과도한 해석으로 사료된다.

9) 리픽싱(행사가격조정)이 이루어진 공시일을 기준으로 $\mathrm{CAR}$ 를 분석한 결과, $\mathrm{CAR}(-5,1)$ 과 $\mathrm{CAR}(-10$, $1)$ 이 각각 $-0.83 \%$ 와 $-2.25 \%$ 로 적어도 $5 \%$ 수준에서 유의적이다. 한편 $\operatorname{CAR}(-1,1)$ 과 $\operatorname{CAR}(-3,1)$ 은 유의적이지 않다. 그러나 공시일 전의 주가하락을 공시효과로 보는 Byun and Park(2017)의 해석에 문제가 있다고 판단한다. 왜냐하면 주가의 하락으로 인해 리픽싱이 발생하는데 공시일 전 주가하락을 리픽싱의 공시효과라고 해석하는 것은 전혀 논리적이지 않기 때문이다. 
The Announcement Effects of Convertible Bond Issuances and Refixing Conversion Prices

Yoon(2019)은 2009년 7월부터 2013년 8월말까지 공시된 사모 신주인수권부사채 발행 중에서 최대주주 등의 특수관계인이 사채권자로부터 신주인수권을 매입(환매)한 249건을 대상으로 분석하였다. Yoon(2019)은 최대주주 등이 신주인수권을 행사하여 실제로 얻은 평균 수익률은 $1,441 \%$ 인데 대략 절반에 해당되는 $674 \%$ 포인트는 리픽싱옵션으로 인한 혜택이고 나머지는 터무니없이 낮은 신주인수권의 가격에 기인한다고 판단한다.

Yoon(2015a), Byun and Park(2017), Yoon(2019)이 리픽싱조항의 문제점을 재무적으로 접근한데 반하여, $\operatorname{Kim}(2001), \operatorname{Lee}(2009), \operatorname{Kang}(2016)$ 은 리픽싱조항의 위법성을 논의한다. $\operatorname{Kim}(2001)$ 은 리픽싱옵션의 위법성을 논의하면서 리픽싱옵션이 부여되면 이는 할인발행을 하는 셈이며 기존주주의 지분적 권리를 크게 침해하므로 금지되어야 한다고 주장한다. Lee(2009)는 리픽싱조항이 현실적 필요성에 의해 포함되기는 하지만 기존주주로부터 투자자로의 부의 이전(wealth transfer) 문제, 기존주주의 보호 문제 등에 대해 공론화가 필요하다고 제안한다.

Kang(2016)은 2014년 대법원 판결(주가가 하락하면 BW의 신주인수권 행사가격의 리픽싱을 인정하면서, 반희석화조항에 의하여 신주인수권 행사가격이 조정된 후에도 다시 주가가 하락하는 경우 리픽싱조항에 의한 신주인수권 행사가격의 최저한도를 다시 조정할 수 있다는 판결)에 대하여 신주인수권 행사가격의 조정은 상법상의 수권자본제도, 주식의 시가발행, 신주인수권 행사가액의 확정 및 주주총회의 권한을 침해하거나 위반하는 문제를 야기할 뿐만 아니라 원래 상법이 예정하고 있지 아니한 방법으로 신주인수권부사채를 발행하는 것을 허용하는 결과가 된다고 주장한다.10)

\section{3. 표본구성과 연구방법}

\section{1 표본 구성}

전환사채 발행 공시효과를 분석하기 위한 연구 표본을 구성하기 위하여 먼저 한국거래소의 상장공시시스템(KIND)에서 2015년 1월부터 2018년 12월까지 “전환사채권발행” 으로 검색한 전환사채발행 공시자료에 다음의 제약조건을 부여한다.

(1) 금융업은 제외하며 유가증권시장 또는 코스닥시장에 상장되어 있다.

(2) 공시일을 전후하여 -150 일부터 +20 일까지 수익률자료가 존재한다.

(3) 해외전환사채를 제외한 국내 전환사채로 제한하며, 하루에 2 건 이상의 전환사채가 공시되면 한 건으로 통합한다.11)

10) 코스닥 상장법인 헤스본은 2009년 6월 25일 이사회에서 $\mathrm{BW}$ 의 발행을 의결하였다. 행사가격은 2,580 원이고 리픽싱은 액면가까지 허용된다고 공시되었다. 2010년 6월 25일 액면가 500원까지 리픽싱이 이루어지고, 이후 헤스본은 10 주를 1 주로 병합하는 주식병합을 실시하여 행사가격이 5,000 원으로 조정되었다. 이후 주가가 추가적으로 하락하자 2011년 9월 25일 행사가격을 798원으로 하향조정하는 절차의 이행을 요구하는 소송이 제기되었는데 반희석화조항 적용 후 리픽싱조항을 다시 적용할 수 있는지가 소송의 핵심 내용이다.

11) 2 건 이상인 경우 발행금액은 합산하지만 나머지 발행조건은 발행금액이 큰 건의 조건을 이용한다 (발행금액이 동일하면 만기가 긴 건을 이용함). 
(4) 발행기업의 보통주로 전환할 수 있는 전환사채로 제한한다(대상이 우선주인 경우 제외함).

(5) 공모 발행은 제외한다. ${ }^{12)}$

(6) 회귀분석에 필요한 변수(총자산, $\mathrm{ROA}, \mathrm{OCF}, \mathrm{LEV}$, 토빈 $\mathrm{q}$ 비율, 대주주지분율 등)의 자료가 존재한다.13)

이상의 조건을 부여한 결과 총 1,421 건의 사모 전환사채 발행 공시자료가 확보되었다(발행 기업은 529개). 1,421 건 중에서 유가증권시장 기업이 공시한 전환사채발행건은 233건(16.4\%) 이고 코스닥기업이 공시한 전환사채발행건은 1,188건(83.6\%)이다. 연도별로는 2015년, 2016년, 2017년, 2018년 공시건이 각각 238(16.7\%), 368(25.9\%), 386(27.2\%), 429(30.2\%)건이다. 그리고 1,421 건을 공시한 기업의 수는 529 개인 데 일부 기업의 경우 계속적으로 전환사채를 발행하는 경향을 보인다. 예를 들어, 포티스는 4년 동안 전환사채를 총 19회 발행하였다.

1,421 건의 전환사채 발행기업의 기초 통계량은 <표 $2>$ 의 패널 $\mathrm{A}$ 와 같다. 총자산은 자산의 장부가치(억 원)이고, $\mathrm{ROA}$ 는 총자산순이익률로 순이익을 총자산으로 나눈 값이고, $\mathrm{OCF}$ 는 영업현금흐름을 총자산으로 나눈 값이고, $\mathrm{LEV}$ 는 총부채를 총자산으로 나눈 부채구성비율이다. 토빈 $\mathrm{q}$ 비율은 부채의 장부가치에 자본의 시장가치(보통주 시가총액과 우선주 시가총액의 합)를 합산한 후 이를 자산의 장부가치로 나눈 비율로 성장기회의 대용변수이다. 그리고 대주주지분율은 최대주주와 특수관계인의 지분율이다.

먼저, $\mathrm{ROA}$ 와 $\mathrm{OCF}$ 에 대한 통계는 전환사채 발행기업의 영업성과가 좋지 않음을 보여준다(ROA 평균은 $-10.9 \%$ 이고 $\mathrm{OCF}$ 평균은 $-3.9 \%$ 임). 그리고 토빈 $\mathrm{q}$ 비율은 평균은 2.8 인데 이는 전환사채 발행기업이 주로 성장기회가 많은 기업임을 의미한다. 패널 $\mathrm{B}$ 는 전환사채 발행과 관련된 통계이다. 평균 조달금액은 140 억 원이고 전환주식비율(전환권 행사로 인해 전환될 주식수를 총발행주식수로 나눈 비율임)은 평균 $11 \%$ 이다. 그리고 발행된 전환사채의 표면이자율은 $1.5 \%$ 이고 만기수익률은 $3.3 \%$ 이다.

본 연구는 전환사채 발행 공시효과 뿐만 아니라 전환가격이 조정되는 경우(리픽싱옵션이 있는 경우)의 공시효과를 함께 분석하고자 한다. 리픽싱옵션이 포함된 경우는 1,355 건으로 $95.4 \%$ 를 점유한다. <표 2>의 패널 C에 의하면, 리픽싱옵션이 있는 경우 리픽싱 또는 전환가격의 하향조정은 대부분 3 개월 간격으로 이루어지는데 1 개월 간격도 대략 3 건당 1 건으로 이용된다. 또한 리픽싱이 허용되는 경우 $64.4 \%$ 의 경우 최초 전환가액의 $70 \%$ 까지 하향조정되고, $28.9 \%$ 의 경우 리픽싱이 훨씬 크게 가능하여 액면가까지 하향조정된다. 그리고 $5.8 \%$ 인 79 건의 경우 $70 \%$ 를 초과하여 리픽싱이 제한된다.

전환가액조정 공시일 자료는 한국거래소의 $\mathrm{KIND}$ 시스템에서 “전환가액의조정”을 보고서명 으로 하여 구하며 전환사채 발행 공시표본인 1,421 건을 발행한 529 개 기업으로 한정한다. 최종적으로 구해진 표본은 2015년부터 2018년까지 4년 동안 전환가액이 조정된 1,798건이다.

12) 2015년부터 2018년까지의 기간 중 공모로 발행된 전환사채는 단 17 건에 지나지 않는다.

13) 회귀분석에 필요한 재무제표 자료는 KISVALUE, 수익률자료는 FnGuide를 이용한다. 
The Announcement Effects of Convertible Bond Issuances and Refixing Conversion Prices

〈표 2〉기초 통계량

총자산은 자산의 장부가치(억 원)이고, $\mathrm{ROA}$ 는 총자산순이익률로 순이익을 총자산으로 나눈 값이고, $\mathrm{OCF}$ 는 영업현금흐름을 총자산으로 나눈 값이고, $\mathrm{LEV}$ 는 총부채를 총자산으로 나눈 부채구성비율이다. 토빈 $\mathrm{q}$ 비율은 부채의 장부가치에 자본의 시장가치(보통주 시가총액과 우선주 시가총액의 합)를 합산한 후 이를 자산의 장부가치로 나눈 비율로 성장기회의 대용변수이다. 그리고 대주주지분율은 최대주주와 특수관계인의 지분율이다. 전환주식비율은 전환권 행사로 전환될 주식수를 총발행주식수로 나눈 비율이다. 패널 $\mathrm{A}$ 에서 $\mathrm{ROA}, \mathrm{OCF}$, 토빈 $\mathrm{q}$ 비율의 경우 상하위 각 $1 \%$ 에 대하여 winsorization을 실시한다. 패널 $\mathrm{A}$ : 발행기업의 특성

\begin{tabular}{lrrrrrr}
\hline \multicolumn{1}{c}{ 변수 } & 평균 & 중앙값 & 최소값 & $25 \%$ & $75 \%$ & 최대값 \\
\hline 총자산(억 원) & 1,421 & 669 & 79 & 406 & 1,241 & 188,803 \\
$\mathrm{ROA}(\%)$ & -10.9 & -4.5 & -98.9 & -19.2 & 1.8 & 22.8 \\
$\mathrm{OCF}(\%)$ & -3.9 & -2.1 & -41.4 & -9.1 & 3.6 & 20.2 \\
$\mathrm{LEV}(\%)$ & 48 & 49 & 2 & 34 & 63 & 150 \\
토빈 q비율 & 2.8 & 1.6 & 0.4 & 1.1 & 2.6 & 25.9 \\
대주주지분율(\%) & 26 & 22 & 0.0 & 13 & 34 & 84 \\
\hline
\end{tabular}

패널 $\mathrm{B}$ : 전환사채발행 관련 통계량

\begin{tabular}{lcccccr}
\hline \multicolumn{1}{c}{ 변수 } & 평균 & 중앙값 & 최소값 & $25 \%$ & $75 \%$ & 최대값 \\
\hline 발행금액(억 원) & 140 & 75 & 2 & 32 & 150 & 12,848 \\
표면이자율(\%) & 1.5 & 0.5 & 0.0 & 0.0 & 2.0 & 12.0 \\
만기수익률(\%) & 3.3 & 3.0 & 0.0 & 2.0 & 5.0 & 15.0 \\
전환주식비율(\%) & 11.0 & 6.9 & 0.1 & 3.0 & 13.4 & 721.0 \\
\hline
\end{tabular}

패널 C: 리픽싱옵션

\begin{tabular}{|c|c|c|}
\hline 구분 & 내용 & \\
\hline 기피시 저요 어비 & \multicolumn{2}{|c|}{ 적용 : 1,355 건 $(95.4 \%)$} \\
\hline 디빅잉 식푱 여부 & 미적용 : & 66건 $(4.6 \%)$ \\
\hline \multirow{4}{*}{$\begin{array}{l}\text { 리픽싱 주기 } \\
\text { (n=1,355) }\end{array}$} & 1개월 : & 401건(29.6\%) \\
\hline & 3개월 : & 894건(66.0\%) \\
\hline & 기타 : & 60건(4.4\%) \\
\hline & $70 \%:$ & 873건(64.4\%) \\
\hline \multirow{3}{*}{$\begin{array}{l}\text { 리픽싱 비율 } \\
\quad(\mathrm{n}=1,355)\end{array}$} & 액면까지 : & 391건(28.9\%) \\
\hline & $70 \%$ 초과, $100 \%$ 미만 : & 79건(5.8\%) \\
\hline & 명기하지 않음 : & 12건 $(0.1 \%)$ \\
\hline
\end{tabular}

\section{2 방법론}

\subsection{1 초과수익률 추정}

전환사채 발행과 관련하여 공시효과를 측정하기 위한 초과수익률 $\mathrm{AR}(\mathrm{abnormal} \mathrm{return:}$ $\mathrm{AR})$ 은 다음과 같은 시장조정수익률모형을 이용한다.

$$
A R_{j t}=r_{j t}-r_{m t}
$$


단, $A R_{j t}$ 는 $j$ 기업의 $t$ 일의 초과수익률, $r_{j t}$ 는 $j$ 기업의 $t$ 일의 수익률, 그리고 $r_{m t}$ 는 주가지수의 $t$ 일의 수익률이다. 시장수익률로 종합주가지수(KOSPI) 또는 코스닥지수를 이용한다. 그리고 다음과 같은 시장모형을 이용한 결과도 추가로 보고한다.

$$
A R_{j t}=r_{j t}-\left(\widehat{\alpha_{j}}+\hat{\beta}_{j} r_{m t}\right)
$$

$\hat{\alpha}$ 와 $\hat{\beta}$ 는 공시일 21 일전부터 150 일전까지의 일별수익률에 적용하여 최소자승법을 통해 추정한다.

그리고 공시일을 전후한 $-k$ 일부터 $+k$ 일까지의 $j$ 기업의 누적초과수익률 CAR(cumulative abnormal return)은 다음과 같이 구하며 평균 $\mathrm{CAR}$ 이 0과 상이한가를 검증하기 위하여 t검증을 실시한다.

$$
C A R(-k,+k)=\sum_{t=-k}^{k} A R_{j t}
$$

\subsection{2 회귀 모형}

리픽싱옵션이 전환사채 발행의 공시효과에 미치는 영향을 분석하기 위하여 두 표본간 차이에 대하여 $\mathrm{t}$-검증을 실시함과 동시에 표본간 차이를 통제하기 위하여 다음과 같은 회귀모형을 적용하기로 한다.

$$
\begin{aligned}
C A R= & \alpha_{0}+\beta_{1} \ln (\text { asset })+\beta_{2} L E V+\beta_{3} O C F+\beta_{4} R O A+\beta_{5} \text { Ownership } \\
& +\beta_{6} Q+\beta_{7} \text { ratio }+\beta_{8} R E F L X+\text { year dummy }+ \text { industry dummy }+\epsilon
\end{aligned}
$$

여기서 REFIX는 더미변수로 리픽싱옵션이 포함되면 1의 값을 갖는다. 그리고 ratio는 전환주식 비율로 전환가능한 주식을 총발행주식수로 나눈 값이다. $\ln$ (asset)은 총자산 장부가치에 자연 대수를 취한 값이고, $\mathrm{OCF}$ 는 영업현금흐름을 총자산으로 나눈 값이고, $\mathrm{ROA}$ 는 순이익을 총자산으로 나눈 값이고, $\mathrm{LEV}$ 는 부채의 장부가치를 총자산으로 나눈 값이다. Ownership은 최대주주와 특수관계인의 지분율이고 $\mathrm{Q}$ 는 토빈의 $\mathrm{q}$ 비율로 부채의 장부가치에 자본의 시장가치 (보통주 시가총액과 우선주 시가총액의 합)를 합산한 후 이를 자산의 장부가치로 나눈 비율이다. 그리고 종속변수로 3 일과 5일 누적초과수익률인 $\mathrm{CAR}(-1,1)$ 과 $\mathrm{CAR}(-2,2)$ 을 이용하며 연도 효과와 산업효과를 통제하기 위하여 더미변수를 사용하고 통제변수는 발행 전년도말 기준이다.

\section{3 검증 가설}

2절의 기존연구 요약에 설명되어 있듯이, 전환사채에 대한 공시효과는 여러 연구에서 이루어 졌으나, 공시효과가 비유적이거나(Kwon et al., 1992; Kho and Park, 2000; Jung and Cha, 2009) 또는 유의적이더라도 양(+)으로 보고되기도 하고(Yun and Jeong, 2001; Park and Baek, 2003; Oh and Kim, 2013; Kim and Han, 2019), 음(-)으로 보고되기도(Woo, 1995; Kwak, 2012; Byun and Park, 2017) 한다. 신주인수권부사채의 경우 우리나라에서 공시효과는 양으로 
The Announcement Effects of Convertible Bond Issuances and Refixing Conversion Prices

유의적인데(Yoon, 2015b; Oh and Kim, 2013),14) 전환사채에 적용되는 리픽싱옵션이 신주인수권 부사채에도 적용되는 등 두 가지 옵션부사채가 유사하고 최근 $\mathrm{CB}$ 의 발행조건이 예전보다 유리하다는 점을 감안하면 전환사채의 공사효과도 양으로 예상된다.15) 또한 대리인비용을 감소시키거나(Green, 1984; Shleifer and Vishny, 1986) 또는 투자기회에 대한 정보를 전달하여 (McConnell and Muscarella, 1985) 기업가치를 증가시킬 수도 있다. 그리고 모니터링가설 (Shleifer and Vishny, 1986; Wruck, 1989)과 보증가설(Hertzel and Smith, 1993)도 양의 공시효과를 예측한다. 그러나 비교적 최근의 연구에서도 음의 공시효과가 보고되기도 하므로 다음과 같은 첫 번째 경쟁가설이 도출된다.

H1a: 전환사채발행 공시효과는 양 $(+)$ 으로 유의적이다.

$\mathrm{H} 1 \mathrm{~b}$ : 전환사채발행 공시효과는 음 $(-)$ 으로 유의적이다.

그리고 공시효과는 리픽싱옵션의 포함 여부에 의해 영향을 받을 것으로 판단된다. 리픽싱옵션이 투자자에게 일방적으로 유리한 조항이라는 것은 기존 주주 입장에서는 불리한 조항이라는 것을 의미하므로, 리픽싱옵션을 포함하여 전환사채를 발행하는 경우의 공시효과가 리픽싱옵션을 포함하지 않는 전환사채의 공시효과보다 유의적으로 작을 것으로 예상된다. 따라서 다음과 같은 두 번째 가설이 유도된다.

$\mathrm{H} 2$ : 리픽싱옵션이 포함된 전환사채의 공시효과가 리픽싱옵션이 포함되지 않은 전환사채의 공시효과보다 작다.

리픽싱옵션이 투자자에게만 유리한 조항이고 또한 리픽싱옵션이 초과수익률을 하락시키는 요인으로 작용한다면 리픽싱옵션이 적용되어 전환가격이 하향조정되는 내용이 공시되면 자본시장은 이에 대해 부정적으로 반응할 것으로 예상되어, 다음과 같은 세 번째 가설이 도출된다.

H3: 리픽싱조항이 포함된 전환사채의 경우 전환가격이 하향조정되는 “전환가액조정(리픽싱)”의 공시효과가 음 $(-)$ 이다.

\section{4. 실증 결과}

\section{1 전환사채발행의 공시효과}

전환사채 발행의 공시효과는 <표 $3>$ 과 같다. 패널 $\mathrm{A}$ 는 공시일을 전후하여 -10 일부터 +5 일까지 일별 초과수익률(abnormal return: $\mathrm{AR})$ 을 시장조정모형과 시장모형으로 계산한 결과이다.

14) 최대주주 등이 발행과 동시에 신주인수권을 사채권자로부터 매입하는 환매기업의 경우 공시효과는 음으로 유의적이다(Yoon, 2019).

15) 신주인수권부사채의 공시효과를 분석한 논문으로 Yoon(2015b)과 Oh and Kim(2013) 이외에 Kang and Baek(2003), Kim et al.(1997), Jinn(2011)의 연구가 있는데, 세 연구 모두 유의적인 공시효과를 발견하지 못하였다. 
한국증권학회지 제49권 2호 (2020)

먼저 전체적으로 매우 유의적이고 긍정적인 공시효과를 확인할 수 있다. 여기서 공시일은 공시시간을 반영하여 장후에 공시되는 경우 익일을 공시일로 변경하였다. Yoon et al.(2017)은 2002년부터 2012년까지 공시된 유상증자 1,667건을 분석한 결과 유상증자의 $82.8 \%$ 가 장후에 공시되며, 장후에 공시되는 경우 익일을 공시일로 변경하면 유상증자의 공시효과가 공시일에 가장 크다고 보고한다(공시시간을 고려하지 않으면 익일에 공시효과가 가장 크게 나타남). 이는 실증연구에 공시시간을 반영하면 공시효과를 보다 정확하게 추정할 수 있음을 시사한다.

\section{〈표 3〉 전환사채발행 공시일 전후의 초과수익률}

이 표는 전환사채발행의 공시일을 전후한 초과수익률(AR)을 분석한다. 장후에 공시되면 익일을 공시일로 변경한다. 여기서 초과수익률은 시장조정모형과 시장모형을 이용하여 추정한다. 시장모형의 경우 비사건 기간은 -150 일부터 -21 일까지이다. *, ** , ***는 각각 $10 \%, 5 \%, 1 \%$ 수준에서 통계적으로 유의함을 의미한다. 중앙값에 대해서는 Wilcoxon signed rank test를 적용한다. 관찰치는 1,421 개이다.

패널 $\mathrm{A}$ : 공시일 전후 일별 초과수익률

\begin{tabular}{|c|c|c|c|c|c|c|}
\hline \multirow{2}{*}{$\begin{array}{l}\text { 공시일 } \\
\text { 기준 }\end{array}$} & \multicolumn{4}{|c|}{ 시장조정모형 $\mathrm{AR}$} & \multicolumn{2}{|c|}{ 시장모형 $\mathrm{AR}$} \\
\hline & 평균 & t-value & 중앙값 & $A R>0$ 비율 & 평균 & t-value \\
\hline-10 & 0.0012 & 1.11 & $-0.0026^{* *}$ & $45 \%$ & 0.0004 & 0.40 \\
\hline-9 & 0.0000 & 0.03 & $-0.0025^{* *}$ & $45 \%$ & -0.0009 & -0.81 \\
\hline-8 & 0.0035 & $3.02^{* * *}$ & 0.0000 & $50 \%$ & 0.0024 & $2.04^{* *}$ \\
\hline-7 & 0.0024 & $2.14^{*}$ & -0.0018 & $46 \%$ & 0.0015 & 1.31 \\
\hline-6 & 0.0042 & $3.80^{* * *}$ & -0.0002 & $49 \%$ & 0.0035 & $3.13^{* * * *}$ \\
\hline-5 & 0.0043 & $3.78^{* * *}$ & $-0.0005^{*}$ & $49 \%$ & 0.0033 & $2.87^{* * *}$ \\
\hline-4 & 0.0036 & $3.14^{* * *}$ & -0.0017 & $47 \%$ & 0.0026 & $2.24^{* *}$ \\
\hline-3 & 0.0044 & $3.73^{* * *}$ & $-0.0005^{*}$ & $49 \%$ & 0.0035 & $2.94^{* * *}$ \\
\hline-2 & 0.0087 & $6.91^{* * *}$ & $0.0018^{* * *}$ & $53 \%$ & 0.0076 & $5.96^{* * *}$ \\
\hline-1 & 0.0287 & $14.50^{* * *}$ & $0.0071^{* * *}$ & $59 \%$ & 0.0278 & $13.96^{* * *}$ \\
\hline 0 & 0.0122 & $6.26^{* * *}$ & $0.0017^{* * *}$ & $52 \%$ & 0.0109 & $5.55^{* * *}$ \\
\hline 1 & 0.0057 & $3.53^{* * *}$ & -0.0021 & $46 \%$ & 0.0044 & $2.73^{* * * *}$ \\
\hline 2 & 0.0029 & $2.18^{* *}$ & $-0.0018^{*}$ & $47 \%$ & 0.0016 & 1.22 \\
\hline 3 & 0.0003 & 0.23 & $-0.0035^{* * *}$ & $43 \%$ & -0.0009 & -0.73 \\
\hline 4 & 0.0011 & 0.80 & $-0.0033^{* * *}$ & $45 \%$ & 0.0002 & 0.12 \\
\hline 5 & -0.0005 & -0.42 & $-0.0037^{* * *}$ & $44 \%$ & -0.0013 & -1.10 \\
\hline
\end{tabular}

패널 $\mathrm{B}$ : 공시일 전후 누적초과수익률

\begin{tabular}{lcccc}
\hline \multirow{2}{*}{ 누적기간 } & \multicolumn{4}{c}{ 시장조정모형 $\mathrm{AR}$} \\
\cline { 2 - 5 } & 평균 & $\mathrm{t}$-value & 중앙값 & $\mathrm{CAR}>0$ 비율 \\
\hline $\mathrm{CAR}(-1,1)$ & 0.0466 & $11.99^{* * *}$ & $0.0124^{* * * *}$ & $58 \%$ \\
$\mathrm{CAR}(-2,0)$ & 0.0496 & $14.50^{* * *}$ & $0.0165^{* * *}$ & $61 \%$ \\
$\mathrm{CAR}(-2,2)$ & 0.0583 & $12.51^{* * *}$ & $0.0158^{* * *}$ & $58 \%$ \\
$\mathrm{CAR}(-3,3)$ & 0.0630 & $11.81^{* * *}$ & $0.0170^{* * *}$ & $57 \%$ \\
$\mathrm{CAR}(-5,5)$ & 0.0715 & $11.25^{* * *}$ & $0.0154^{* * *}$ & $56 \%$ \\
$\mathrm{CAR}(-10,5)$ & 0.0828 & $11.79^{* * *}$ & $0.0256^{* * *}$ & $57 \%$ \\
\hline
\end{tabular}


The Announcement Effects of Convertible Bond Issuances and Refixing Conversion Prices

가장 큰 주가반응은 공시일 전일에 발생한다. 시장조정모형에 의하면 공시일 전일의 초과 수익률은 $2.87 \%$ 이고 t-value는 14.50 이다. 또한 중앙값도 $0.71 \%$ 로 $1 \%$ 신뢰수준에서 유의적이며 $\mathrm{AR}>0$ 의 비율은 $59 \%$ 이다. 시장모형을 적용하더라도 결과는 거의 차이가 없다(초과수익률은 $2.78 \%$ 이고 $\mathrm{t}-\mathrm{value}$ 는 13.96 임). 공시일의 초과수익률은 전일보다 작지만 여전히 매우 유의적이다. 즉, 초과수익률은 $1.22 \%$ 이고 t-value는 6.26 이다. 그리고 공시 이틀 전에도 초과수익률이 $0.87 \%$ 로 상당히 유의적인 주가상승이 보인다.

한편 -8 일부터 -3 일까지의 경우 초과수익률도 대체로 양으로 유의적이지만 중앙값이 거의 대부분 음수로 산출되어 이 기간 동안 주가상승이 있다고 주장하기에는 무리가 있다. 평균과 중앙값을 함께 이용하여 판단할 때, 결국 공시효과는 -2 일부터 0 일까지 발생하며 공시시간을 반영하여 공시일을 조정했다는 점을 감안하면 $\mathrm{CB}$ 발행에 대한 정보가 사전에 노출된 것으로 판단된다.16) 공시일을 전후한 $\mathrm{CAR}$ 를 표시한 <그림 $1>$ 은 3 일간의 뚜렷한 주가상승을 잘 보여준다.

〈그림 1〉 공시일을 전후한 누적초과수익률(공시일 기준 -15 일부터 +15 일까지)

이 그림은 전환사채 발행 공시표본 1,421 건의 공시일 기준 -15 일부터 +15 일까지의 누적초과수익률의 움직임을 보여준다. 여기서 초과수익률은 시장조정모형으로 계산한다.

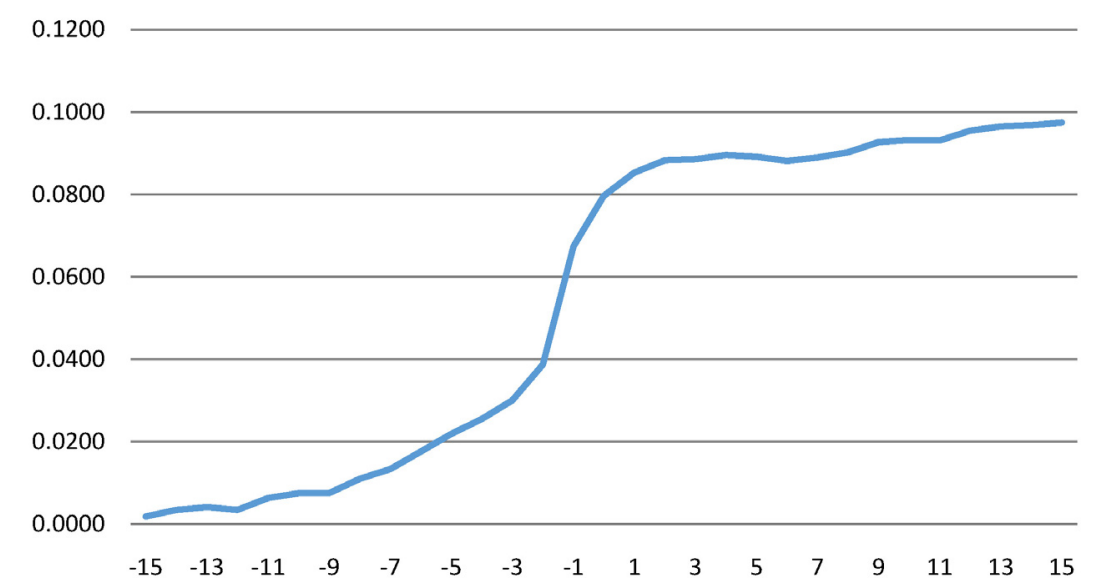

패널 $\mathrm{B}$ 는 시장조정모형으로 계산한 초과수익률을 여러 기간별로 누적한 누적초과수익률 (CAR)이다. 3일, 5일, 7일, 11 일, 16 일 CAR가 4.66\% 8.28\%이며 모두 1\% 신뢰수준에서 유의적 이며, 중앙값(median)도 $1.24 \% \sim 2.56 \%$ 이며 마찬가지로 모두 1\% 신뢰수준에서 유의적이다. 특히 -2 일부터 공시일까지의 3 일 CAR가 가장 큰 $\mathrm{t}-\mathrm{value}$ 와 가장 높은 $\mathrm{CAR}>0$ 의 비율을 보인다. 앞의 기존 연구에서 요약했듯이, 그동안 전환사채발행의 공시효과에 대한 결과는 비유의적이거나 또는 유의적이더라도 양인 경우도 있고 음인 경우도 있었지만, 유의하더라도 방향에 관계없이 초과수익률 또는 누적초과수익률의 규모가 $1 \%$ 대를 초과하지 않았는데 본 연구의 결과는 이와 비교하면 상당히 큰 규모이다. 이는 앞에서 언급했듯이 시장 환경의 변화로

16) Lim et al.(2019)은 제3자배정 유상증자의 공시효과를 분석한 결과 유의적인 양의 공시효과 뿐만 아니라 공시일 이전 -4 일부터의 유의적인 주가상승도 보고하는데 이는 <표 $3>$ 과 유사한 패턴이다. 
한국증권학회지 제49권 2호 (2020)

발행자 중심의 시장이 형성되었고 이로 인해 $\mathrm{CB}$ 발행조건이 예전보다 유리하게 결정된 것도 중요한 이유로 추정된다.

결론적으로 <표 3>과<그림 1>은 가설 $\mathrm{H1a}$ 를 지지하며, 이 결과는 기존 연구 중에서 $\mathrm{Oh}$ and $\operatorname{Kim}(2013)$ 및 $\mathrm{Kim}$ and $\operatorname{Han}(2019)$ 의 결과와 가장 유사하다. 양의 공시효과는 모니터링가설 (Green, 1984; Shleifer and Vishny, 1986; Wruck, 1989)과 보증가설(Hertzel and Smith, 1993)에 의해 설명된다. 두 가설은 참여자가 외부투자자이거나 정보거래자이면 기업가치를 증가시키거나 또는 저평가된 기업가치를 확증할 수 있다고 주장한다.

앞에서 언급했듯이, 일부 기업은 전환사채를 지속적으로 발행하는 경향을 보이므로 이런 기업에 의해 양의 공시효과가 야기될 수도 있다. 따라서 먼저 2건 이상 공시한 기업별 평균 공시효과를 구한 후 다시 전체의 평균을 구한 결과 $(\mathrm{n}=529)$, 공시일 전후 $-2,-1,0$ 일의 초과 수익률은 각각 $0.0079,0.0262,0.0133$ 이고 t-value는 각각 4.89, 10.20, 5.33으로 산출되어 양의 공시효과가 일부 기업이 다수의 전환사채를 발행한 것에 의해 영향을 받지 않았음을 확인할 수 있다 $(<$ 표 $4>$ 의 첫 번째 결과 참조).

또한 <표 $4>$ 에 의하면 유가증권시장과 코스닥시장으로 구분하여 분석한 결과는 거의 차이가 없다. 1,421 건 중에서 유가증권시장 발행건이 233 건으로 $16.4 \%$ 를 점유하고, 코스닥 발행건이 1,188 건으로 $83.6 \%$ 를 점유한다. 3 일간의 초과수익률을 합산한 $\mathrm{CAR}(-1,1)$ 이 유가증권시장의 경우 $4.27 \%$ 이고 코스닥의 경우 $4.73 \%$ 이다.

〈표 4〉 공시효과의 추가분석

이 표는 전환사채발행의 공시일을 전후한 초과수익률 $(\mathrm{AR})$ 을 분석한다. 장후에 공시되면 익일을 공시일로 변경한다. 여기서 초과수익률은 시장조정모형을 이용하여 추정한다. * *****는 각각 $10 \%, 5 \%, 1 \%$ 수준에서 통계적으로 유의함을 의미한다.

\begin{tabular}{|c|c|c|c|c|c|c|}
\hline \multirow{2}{*}{$\begin{array}{c}\begin{array}{c}\text { 공시일 } \\
\text { 기준 }\end{array} \\
-5\end{array}$} & \multicolumn{2}{|c|}{$\begin{array}{c}\text { 발행기업별 평균을 먼저 } \\
\text { 구하는 경우 }(n=529)\end{array}$} & \multicolumn{2}{|c|}{$\begin{array}{c}\text { 유가증권시장 } \\
(\mathrm{n}=233)\end{array}$} & \multicolumn{2}{|c|}{$\begin{array}{l}\text { 코스닥시장 } \\
(n=1,188)\end{array}$} \\
\hline & 0.0046 & $3.61^{* * *}$ & 0.0010 & 0.33 & 0.0050 & $3.99^{* * * *}$ \\
\hline-4 & 0.0032 & $2.58^{* *}$ & 0.0061 & $1.90^{*}$ & 0.0032 & $2.56^{* *}$ \\
\hline-3 & 0.0037 & $2.63^{* * *}$ & 0.0007 & 0.26 & 0.0052 & $3.92^{* * * *}$ \\
\hline-2 & 0.0079 & $4.89^{* * *}$ & 0.0078 & $2.84^{* * *}$ & 0.0089 & $6.31^{* * *}$ \\
\hline-1 & 0.0262 & $10.20^{* * *}$ & 0.0230 & $5.43^{* * *}$ & 0.0298 & $13.46^{* * *}$ \\
\hline 0 & 0.0133 & $5.33^{* * *}$ & 0.0133 & $2.71^{* * *}$ & 0.0120 & $5.64^{* * *}$ \\
\hline 1 & 0.0076 & $3.66^{* * *}$ & 0.0064 & 1.60 & 0.0055 & $3.15^{* * *}$ \\
\hline 2 & 0.0012 & 0.84 & 0.0027 & 0.75 & 0.0030 & $2.06^{* *}$ \\
\hline 3 & 0.0016 & 1.00 & 0.0057 & $1.73^{*}$ & -0.0008 & -0.59 \\
\hline 4 & 0.0023 & 1.55 & -0.0002 & -0.06 & 0.0013 & 0.91 \\
\hline 5 & 0.0006 & 0.44 & -0.0031 & -1.02 & 0.0000 & 0.01 \\
\hline
\end{tabular}

기업이 자금을 조달하게 되면 조달목적을 공시해야 한다. 조달목적은 시설자금, 운영자금, 타법인증권 취득자금, 기타자금으로 구분된다. 유상증자의 경우 Yoon(2016)은 2,163건 중에서 시설투자 목적이 51 건(2.4\%), 운영자금 목적이 1,307건(60.4\%), 투자 및 증권취득 목적이 31 건(1.4\%), 기타목적이 51건(2.4\%)이고 복수의 목적을 표기한 경우가 723 건(33.4\%)이라고 
The Announcement Effects of Convertible Bond Issuances and Refixing Conversion Prices

보고한다.17) 이를 본 연구 표본의 구성비율과 비교하면(<표 $5>$ 의 패널 $\mathrm{A}, 1,421$ 건 기준), 본 연구 표본의 경우 타법인증권 취득자금 목적의 비율이 $13.1 \%$ 로 유상증자의 $1.4 \%$ 와 비교하면 매우 크다는 것을 알 수 있다. 본 연구의 기간인 2015년 2018년은 Yoon(2016)의 연구기간인 1991년 2013년과는 차이가 있지만, 발행기업이 타법인증권에 투자할 자금을 유상증자보다는 전환사채 등의 메자닌금융을 통해 조달하고 있음을 의미한다.

패널 $\mathrm{B}$ 는 목적별로 3 일과 5 일 누적초과수익률을 비교한 것이다. 먼저 시설자금조달을 목적으로 공시하는 경우 표본 수가 다소 작기는 하지만, $\mathrm{CAR}$ 가 작을 뿐만 아니라 전혀 유의적이지도 않음을 확인할 수 있다. 그러나 운영자금과 타법인증권 취득자금을 목적으로 공시하는 경우 각각의 공시효과가 매우 유의적이다(두 수익률간 차이는 거의 없음).

패널 $\mathrm{C}$ 는 시설자금 표본을 운영자금 또는 타법인증권취득자금 표본과 비교한 결과이다. 누적초과수익률의 차이가 $-3.49 \% \sim-5.29 \%$ 이며 적어도 $10 \%$ 신뢰수준에서 유의적이다. 이상의 결과는 기업이 전환사채를 발행하면서 이를 시설자금으로 사용하겠다고 공시하면 시장은 이를 긍정적으로 해석하지 않는다는 증거이다. 이는 기존 사업 투자에서의 성과가 좋지 않음을 의미할 수도 있고 아니면 시설투자 자체에 대해 수익성을 창출할 수 있는 좋은 투자로 인식하지 않는다는 증거일 수도 있고 또는 시설투자에 필요한 자금을 전환사채 발행으로 조달하는 것에 대한 거부감(예를 들어 내부적으로 조달해야 한다고 생각함)일 수도 있다. 시설자금 목적의 공시에 대하여 유의적으로 반응하지 않고 오히려 다른 목적의 공시에 비하여 공시효과가 유의적으로 작다는 것은 전환사채 발행이 기업의 투자기회에 대한 정보를 제공할 수 있다는 논리(McConnell and Muscarella, 1985)가 우리의 경우 해당되지 않음을 의미한다.

그리고 또 하나 흥미로운 사실은 기업이 타법인의 증권을 취득할 목적으로 전환사채를 발행하는 것에 대하여 시장이 매우 긍정적으로 평가하고 있다는 점이다. 타법인 주식 및 출자증권을 취득하는 목적으로 언급되는 주된 이유는 사업다각화, 수익구조 개선, 경영참여, 유상증자참여 등인데, 외부투자자 또는 정보거래자가 참여하는 사모 전환사채 발행에서 타법인 증권 취득은 유망한 새로운 사업에의 진출을 시그널하는 것으로 평가된다.

시설자금조달이 목적인 $\mathrm{CB}$ 의 공시효과가 다른 목적(용도)을 제시한 $\mathrm{CB}$ 의 공시효과보다 유의적으로 작다는 본 연구의 결과는 $\mathrm{Kim}$ and $\operatorname{Han}(2019)$ 의 연구결과와 완전히 상반된다. Kim and Han(2019)은 2000년부터 2015년까지 공시된 1,508건의 CB 발행건 중에서 조달목적이 명시된 610 건을 분석한 결과 시설자금조달이 목적인 91 건의 공시일 전후 3 일 누적초과수익률이 $3.13 \%$ 인 반면에 다른 목적인 519 건의 누적초과수익률은 $1.74 \%$ 이며 그 차이는 유의적이라고 한다. 정반대의 결과가 나온 이유를 논리적으로 설명할 수는 없지만 이유는 표본이 상이하기 때문으로 판단된다. 즉, 본 연구의 경우 연구기간이 2015 2018년이고 모두 사모발행인 반면에 Kim and $\operatorname{Han}(2019)$ 의 경우 2000 2015년을 대상으로 사모발행이 458건으로 표본의 75\%를 점유한다. 또한 자금조달목적 변수의 출처가 상이하다. Kim and Han(2019)은 SDC Platinum's Global New Issues Database를 이용한 반면에 본 연구의 자료는 한국거래소 상장공시시스템에

17) $\operatorname{Yoon}(2016)$ 의 본문 398쪽과 각주 26을 이용하여 저자가 계산함. 
한국증권학회지 제49권 2호 (2020)

업로드된 공시자료(유상증자 주요사항보고서)의 '자금조달의 목적' 항목에서 직접 수작업으로 모은 자료이다.18)

〈표 5〉 전환사채발행 목적별 공시효과 분석

이 표는 전환사채발행 목적별로 초과수익률을 산출하고 비교한 결과이다. 1,421 건 중에서 복수의 목적을 표기한 223 건을 제외한 1,198 건을 대상으로 한다. 초과수익률은 시장조정모형을 이용하여 추정한다. *, **, ${ }^{* * *}$ 는 각각 $10 \%, 5 \%, 1 \%$ 수준에서 통계적으로 유의함을 의미한다.

패널 $\mathrm{A}$ : 목적별 구성비율

\begin{tabular}{lcccc}
\hline & 시설자금 & 운영자금 & 타법인증권 취득자금 & 기타 자금 \\
\hline 건수 & 39 & 897 & 186 & 76 \\
구성비율(1,198건 기준) & $3.3 \%$ & $74.9 \%$ & $15.5 \%$ & $6.3 \%$ \\
구성비율(1,421건 기준) & $2.7 \%$ & $63.1 \%$ & $13.1 \%$ & $5.3 \%$ \\
\hline
\end{tabular}

패널 $\mathrm{B}$ : 목적별 초과수익률

\begin{tabular}{|c|c|c|c|c|}
\hline \multirow{2}{*}{ 목적 } & \multicolumn{2}{|c|}{$\operatorname{CAR}(-1,1)$} & \multicolumn{2}{|c|}{$\operatorname{CAR}(-2,2)$} \\
\hline & 평균 & t-value & 평균 & t-value \\
\hline 시설자금 & 0.0103 & 0.72 & 0.0097 & 0.54 \\
\hline 운영자금 & 0.0494 & $10.06^{\text {*** }}$ & 0.0585 & $10.03^{* * *}$ \\
\hline 타법인증권취득자금 & 0.0452 & $4.05^{* * *}$ & 0.0626 & $4.60^{* * * *}$ \\
\hline 기타 자금 & 0.0306 & $2.13^{* *}$ & 0.0403 & $2.28^{* *}$ \\
\hline
\end{tabular}

패널 $\mathrm{C}$ : 그룹간 비교

\begin{tabular}{lccccc}
\hline & \multicolumn{2}{c}{ (시설자금-운영자금) } & & \multicolumn{2}{c}{ (시설자금-타법인증권취득자금) } \\
\cline { 2 - 3 } \cline { 5 - 6 } & 차이 & t-value & & 차이 & t-value \\
\hline $\operatorname{CAR}(-1,1)$ & -0.0391 & $-2.57^{* *}$ & & -0.0349 & $-1.91^{*}$ \\
$\mathrm{CAR}(-2,2)$ & -0.0488 & $-2.59^{* *}$ & & -0.0529 & $-2.35^{* *}$ \\
\hline
\end{tabular}

\section{2 리픽싱옵션 여부가 공시효과에 미치는 영향}

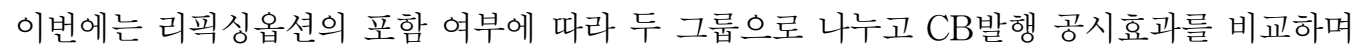
결과는 <표 $6>$ 에 제시되어 있다. 1,421 건 중에서 리픽싱옵션이 포함된 경우는 1,355 건(95.4\%) 이고 리픽싱옵션이 포함되지 않은 경우 66건(4.6\%)이다. 패널 $\mathrm{A}$ 는 공시일 전후 일별 초과수익률을 분석한 결과인데 옵션의 포함 여부와 무관하게 모두 유의적인 양의 결과를 보여준다. 리픽싱옵션이 포함되지 않은 경우 공시일 전일과 공시일에서 초과수익률이 각각 $3.50 \%$ 와 $2.83 \%$ 이고 t-value는 각각 3.47 과 2.38 이다. 그리고 리픽싱옵션이 포함된 경우 공시일 전일과 공시일에서 초과수익률이 각각 $2.84 \%$ 와 $1.14 \%$ 이고 $\mathrm{t}-\mathrm{value}$ 는 각각 14.08 과 5.82 이다.

18) 본 연구의 경우 조달목적이 시설자금인 경우는 39 건으로 1,421 건의 $2.7 \%$ 를 점유하는 반면에 $\mathrm{Kim}$ and $\operatorname{Han}(2019)$ 의 경우 91 건으로 610 건의 $14.9 \%$ 를 점유한다. 우리의 연구에서 시설자금과 다른 용도를 함께 표기하는 경우는 여기에 포함되지 않는다. 2015년이 두 연구에 모두 포함되므로 2015년의 자료를 비교해 보자. Kim and Han의 경우 시설자금목적 38건, 기타 목적 183건인데 반해, 본 연구의 경우 시설자금목적 단 2건, 기타 목적 236건이다(시설자금과 다른 용도를 함께 공시하지만 시설자금에 가장 큰 금액을 배정한 경우까지 포함하면 11건임). 
The Announcement Effects of Convertible Bond Issuances and Refixing Conversion Prices

패널 $\mathrm{B}$ 는 여러 기간별 누적초과수익률을 비교한 결과이다. 리픽싱옵션이 포함되지 않은 경우가 포함된 경우보다 누적초과수익률이 항상 크게 나오지만 차이가 유의미하지는 않다. 예를 들어, 공시일 전후 3 일간의 누적초과수익률인 $\mathrm{CAR}(-1,1)$ 의 경우 리픽싱옵션이 포함되면 $4.47 \%$ 이고 포함되지 않으면 $8.51 \%$ 이며 차이는 $4.04 \%$ 인데 유의적이지 않다.19)20)

〈표 6〉리픽싱옵션 포함 여부에 따른 공시효과의 비교

이 표는 전환사채발행의 공시일을 전후한 초과수익률(AR)을 리픽싱옵션 포함 여부에 따라 분석한다. 장후에 공시되면 익일을 공시일로 변경한다. 여기서 초과수익률은 시장조정모형을 이용하여 추정한다. ${ }^{*},{ }^{* *},{ }^{* * *}$ 는 각각 $10 \%, 5 \%, 1 \%$ 수준에서 통계적으로 유의함을 의미한다.

패널 $\mathrm{A}$ : 공시일 전후 일별 초과수익률

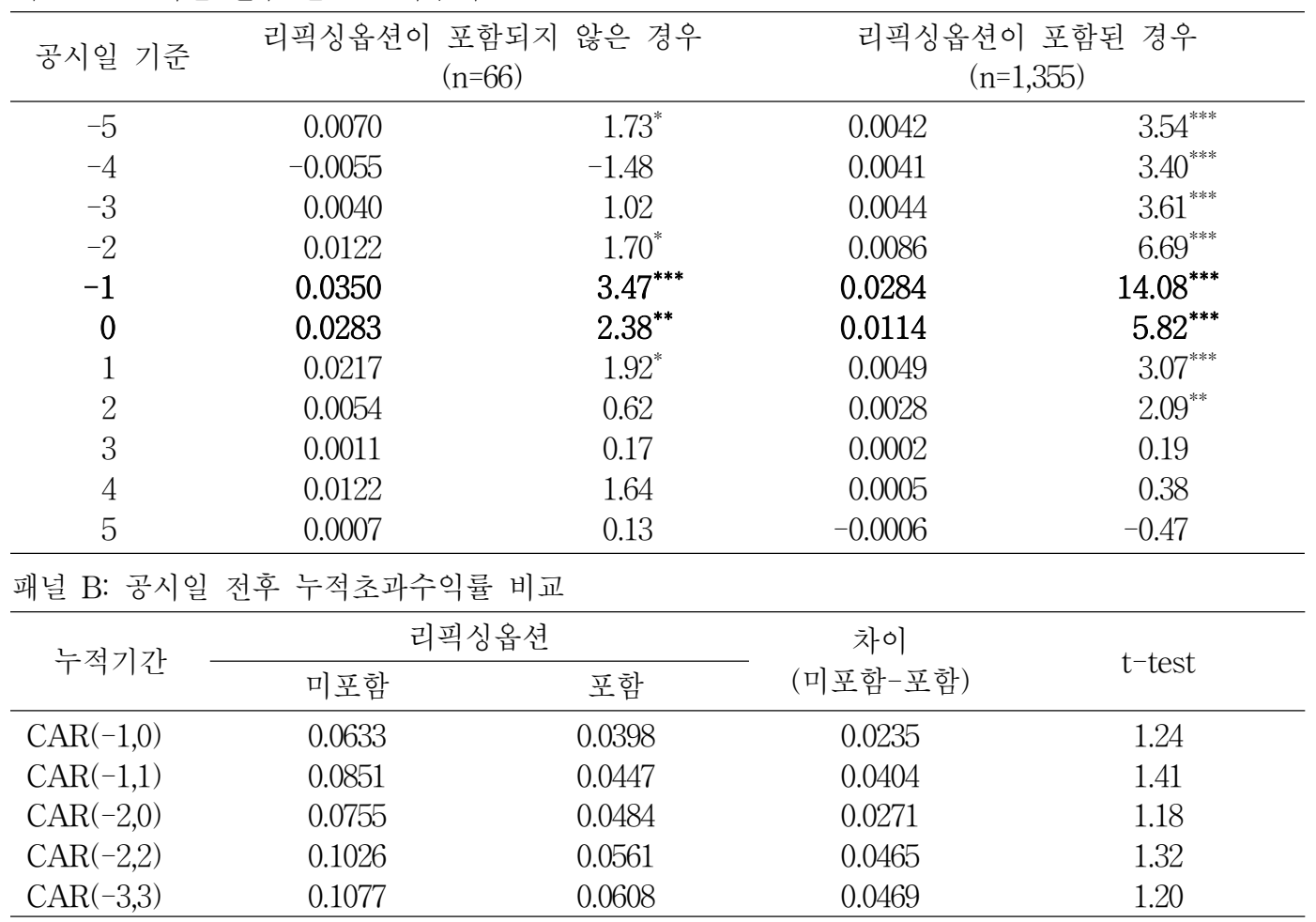

19) 추가적으로 리픽싱옵션이 포함되는 경우, 리픽싱의 비율을 기준으로 리픽싱이 $70 \%$ 까지 허용되는 그룹과 리픽싱이 액면가까지 허용되는 그룹을 구성하고 두 그룹의 초과수익률을 비교하였으나 차이가 거의 없는 것으로 분석된다.

20) 본 연구에 앞서 Byun and Park(2017)이 전환사채 발행의 공시효과와 리픽싱옵션 유무에 따른 공시효과 차이를 분석하였다. 각주 8)과 9)에 설명되어 있듯이 Byun and Park(2017)은 음의 공시효과를 보고한다는 측면에서 본 연구와 차이가 크다. Byun and Park(2017)은 2000년부터 2015년까지의 기간을 대상으로 813건의 표본을 구성하였는데, 리픽싱 포함 650건과 리픽싱 불포함 163 건의 비율은 최근보다 2000년 대 초반의 $\mathrm{CB}$ 발행이 상대적으로 많이 포함되었음을 시사한다. 왜냐하면 2010년 이후 리픽싱옵션 포함비율은 대략 $95 \%$ 인데 표본의 경우 $650 / 813=80 \%$ 에 지나지 않기 때문이다(Byun and Park, 2017, <Table 1>). 
리픽싱옵션이 포함되지 않은 경우와 포함되는 경우가 여러 기준에서 상이할 수 있으므로 두 그룹간 공시효과에서 유의적인 차이가 존재하는지 측정하는 보다 정확한 방법은 두 표본간 차이를 통제할 수 있는 회귀분석이다. 회귀분석시 연도 및 산업효과를 통제하기 위해 연도더미와 산업더미를 이용하며 결과는 <표 $7>$ 과 같고 종속변수로 3 일과 5 일 누적초과수익률을 이용한다 (시장조정모형 이용).21)

\section{〈표 7〉회귀분석}

회귀식의 종속변수는 전환사채발행 공시일을 전후한 누적초과수익률이다(시장조정모형 이용). 총자산은 자산의 장부가치(억 원)이고, $\mathrm{ROA}$ 는 총자산순이익률로 순이익을 총자산으로 나눈 값이고, $\mathrm{OCF}$ 는 영업현금흐름을 총자산으로 나눈 값이고, $\mathrm{LEV}$ 는 총부채를 총자산으로 나눈 부채구성비율이다. 토빈 $\mathrm{q}$ 비율은 부채의 장부가치에 자본의 시장가치(보통주 시가총액과 우선주 시가총액의 합)를 합산한 후 이를 자산의 장부가치로 나눈 비율로 성장기회의 대용변수이다. 그리고 대주주지분율(ownership)은 최대주주와 특수관계인의 지분율이다. 전환주식비율(ratio)은 전환권 행사로 전환될 주식수를 총발행 주식수로 나눈 비율이다. REFIX는 리픽싱옵션이 포함되면 1 의 값을 갖는 더미변수이다. ROA, OCF, 토빈 $\mathrm{q}$ 비율의 경우 상하위 각 $1 \%$ 에 대하여 winsorization을 실시한 값을 이용한다. ${ }^{*},{ }^{* *},{ }^{* * *}$ 는 각각 $10 \%, 5 \%, 1 \%$ 수준에서 통계적으로 유의함을 의미한다.

\begin{tabular}{|c|c|c|c|c|}
\hline \multirow{2}{*}{ 종속변수 } & \multicolumn{2}{|c|}{ 결과 (1) } & \multicolumn{2}{|c|}{ 결과 (2) } \\
\hline & \multicolumn{2}{|c|}{$\operatorname{CAR}(-1,1)$} & \multicolumn{2}{|c|}{$\operatorname{CAR}(-2,2)$} \\
\hline 절편 & 0.9420 & $4.83^{* * *}$ & 1.2479 & $5.37^{* * *}$ \\
\hline $\ln$ (asset) & -0.0304 & $-5.71^{* * *}$ & -0.0394 & $-6.23^{* * *}$ \\
\hline LEV & -0.0187 & -0.79 & -0.0229 & -0.81 \\
\hline $\mathrm{OCF}$ & 0.0836 & $1.99^{* *}$ & 0.1177 & $2.35^{* *}$ \\
\hline $\mathrm{ROA}$ & -0.0346 & -1.34 & -0.0463 & -1.50 \\
\hline Ownership & 0.0003 & 1.24 & 0.0005 & 1.45 \\
\hline Tobin Q & -0.0007 & -0.55 & -0.0007 & -0.49 \\
\hline ratio & 0.1119 & $6.46^{* * *}$ & 0.1346 & $6.52^{* * *}$ \\
\hline REFIX & -0.0420 & $-2.24^{* *}$ & -0.0469 & $-2.10^{* *}$ \\
\hline 연도더미 & \multicolumn{2}{|c|}{ 사용 } & \multicolumn{2}{|c|}{ 사용 } \\
\hline 산업더미 & \multicolumn{2}{|c|}{ 사용 } & \multicolumn{2}{|c|}{ 사용 } \\
\hline $\mathrm{R}^{2}$ & \multicolumn{2}{|c|}{0.11} & \multicolumn{2}{|c|}{0.12} \\
\hline $\mathrm{F}$-value & \multicolumn{2}{|c|}{$2.89^{* * *}$} & \multicolumn{2}{|c|}{$3.25^{* * *}$} \\
\hline 관찰치 & \multicolumn{2}{|c|}{1,421} & \multicolumn{2}{|c|}{1,421} \\
\hline
\end{tabular}

리픽싱옵션이 포함되는 경우 1 의 값을 갖는 더미변수 REFIX는 모든 회귀식에서 음으로 유의적이다. 이는 리픽싱옵션이 포함되면 수익률에 영향을 미치는 여러 요인을 통제한 후에 누적초과수익률이 4.20\% 4.69\%포인트 유의적으로 하락하는 것으로 해석된다. 대체로 기업 규모가 작을수록, 영업현금흐름이 많을수록, 그리고 발행규모의 대용치인 전환주식비율인 ratio가 높을수록 누적초과수익률이 유의적으로 큰 것으로 나타났다.

21) 다중공선성(multicollinearity)의 존재를 확인하기 하여 분산확대인자(variance inflation factor)를 확인한 결과 모두 2 를 넘지 않은 것으로 나타나 다중공선성의 문제는 없는 것으로 판단된다. 
The Announcement Effects of Convertible Bond Issuances and Refixing Conversion Prices

강건성 검증을 위해 시장모형을 이용하여 리픽싱옵션이 포함되는 경우와 포함되지 않은 경우의 누적초과수익률을 비교하기로 한다. 시장모형을 적용한 결과 <표 $6>$ 의 패널 $\mathrm{B}$ 에서 차이는 각각 $0.0267,0.0465,0.0299,0.0533,0.0551$ 로 시장조정모형의 경우보다 약간 크게 계산되지만 모두 유의적이지 않다. 그리고 시장모형을 적용한 <표 $7>$ 의 회귀분석 결과, REFIX가 각각 -0.0458 과 -0.0498 의 값을 가지며 t값은 각각 -2.42 와 -2.20 이다. 결론적으로 <표 $7>$ 은 두 번째 가설을 지지한다.

\section{3 전환가액 조정의 공시효과}

발행 후 주가가 하락하면 리픽싱옵션에 의해 $\mathrm{CB}$ 의 전환가액은 하향 조정된다. 리픽싱은 통상 다음과 같이 명시된다.

각 전환가액 조정일 전일을 기산일로 하여 그 기산일로부터 소급한 1 개월 가중산술평균 주가, 1 주일 가중산술평균주가 및 기산일 가중산술평균주가를 산술평균한 가액과 기산일 가중산술평균주가 중 높은 가격이 해당 조정일 직전일 현재의 전환가액보다 낮은 경우 동 낮은 가격을 새로운 전환가액으로 한다.

조정된 전환가격은 통상 최초 전환가격의 $70 \%$ 이상이어야 하지만 정관에 명시된 경우 액면가까지 조정이 가능하다. 앞의 <표 $2>$ 의 패널 $\mathrm{C}$ 에 의하면 우리 표본에서 $64.4 \%$ 의 경우 최초 전환가액의 $70 \%$ 까지 하향조정되고, $28.9 \%$ 의 경우 리픽싱이 액면가까지 허용된다. 그리고 리픽싱주기의 경우 표본의 $66 \%$ 에서 리픽싱은 매 3 개월마다 이루어진다. 예를 들어 만기가 3 년이고 리픽싱 주기가 3 개월이면 리픽싱은 총 12 회 발생할 수 있다(현재 규정상 횟수 제한은 없음).

리픽싱 조항은 당연히 사채권자 또는 투자자에게 일방적으로 유리한 조항이므로 전환가격이 조정되면 이는 주주 관점에서 불리한 소식이 될 것이고 주가는 평균적으로 하락하게 될 것이다. <표 8>은 2015년 1월부터 2018년 12월까지 상장공시시스템에 공시된 “전환가액의조정” 공시 자료에서 우리의 $\mathrm{CB}$ 발행 공시자료에 포함된 기업들에 한정하여 표본을 구성하고 초과수익률을 분석한 결과이다(표본은 1,798 건임).

전환가액 조정일 전에 주가가 하락하면 전환가액이 하향조정될 것이고 이 경우 전환가액 조정 공시효과를 분석하면 당연히 전환가액조정 공시일 전에 주가는 유의적으로 하락할 것이다.22) 시장조정모형을 적용한 <표 8>의 결과 (1)에서 -20 일부터 -4 일까지 각각의 일별 초과수익률은 유의적으로 음이다. 그리고 전환가액이 실제로 하향조정된다는 공시가 나오면 시장은 이 뉴스에 대하여 부정적으로 반응한다. ${ }^{23)}$ 공시일의 초과수익률은 $-0.27 \%$ 이고 t-value는 -3.16 인데 이는 $1 \%$ 신뢰수준에서 유의적인 결과이다. 또한 <표 8>의 (2)에서 시장모형을 적용한 결과, 유의성은 다소 하락하지만 공시일의 초과수익률이 $5 \%$ 신뢰수준에서 유의적이다.

22) 각주 9)에서 설명했듯이, 행사가격조정 공시일 이전의 주가하락을 공시효과로 해석하는 것은 논리적 이지 않다.

23) 전환사채발행 공시일과 마찬가지로 전환가액조정의 공시가 장후에 공시되면 익일을 공시일로 변경 한다. 
한국증권학회지 제49권 2호 (2020)

이상의 결과는 전환가액 하향조정의 공시효과가 음이라는 세 번째 가설을 지지하며, <표 6> <표 8>의 결과는 리픽싱옵션의 부정적 효과를 실증적으로 보여주는 최초의 결과이다.

〈표 8〉 전환가액조정 공시일 전후의 초과수익률 분석

이 표는 리픽싱옵션에 의해 $\mathrm{CB}$ 의 전환가액이 하향조정되는 경우 공시일을 전후한 초과수익률을 분석한 표이다. 초과수익률은 시장조정모형과 시장모형을 적용하여 계산된다. 장후에 공시되면 익일을 공시일로 변경한다. *, ${ }^{* *},{ }^{* * *}$ 는 각각 $10 \%, 5 \%, 1 \%$ 수준에서 통계적으로 유의함을 의미한다. 전환가액조정 표본 수는 1,798 이다.

\begin{tabular}{|c|c|c|c|c|}
\hline \multirow{2}{*}{$\begin{array}{l}\text { 전환가격조정 } \\
\text { 공시일 기준 }\end{array}$} & \multicolumn{2}{|c|}{ (1) 시장조정모형 적용 } & \multicolumn{2}{|c|}{ (2) 시장모형 적용 } \\
\hline & 평균 & t-value & 평균 & t-value \\
\hline-20 & -0.0038 & $-4.61^{* * *}$ & -0.0031 & $-3.79^{* * * *}$ \\
\hline-19 & -0.0032 & $-4.19^{* * *}$ & -0.0028 & $-3.69^{* * *}$ \\
\hline-18 & -0.0030 & $-3.88^{* * *}$ & -0.0025 & $-3.16^{* * *}$ \\
\hline-17 & -0.0039 & $-4.74^{* * *}$ & -0.0034 & $-4.17^{* * *}$ \\
\hline-16 & -0.0027 & $-3.29^{* * *}$ & -0.0023 & $-2.77^{\text {*** }}$ \\
\hline-15 & -0.0021 & $-2.35^{* *}$ & -0.0018 & $-2.02^{* *}$ \\
\hline-14 & -0.0027 & $-3.52^{* * * *}$ & -0.0023 & $-2.94^{* * *}$ \\
\hline-13 & -0.0039 & $-4.79^{* * *}$ & -0.0034 & $-4.18^{* * * *}$ \\
\hline-12 & -0.0025 & $-3.11^{* * *}$ & -0.0020 & $-2.37^{* *}$ \\
\hline-11 & -0.0039 & $-4.46^{* * *}$ & -0.0033 & $-3.75^{* * *}$ \\
\hline-10 & -0.0036 & $-3.50^{* * *}$ & -0.0032 & $-3.06^{* * *}$ \\
\hline-9 & -0.0028 & $-3.30^{* * *}$ & -0.0022 & $-2.57^{* *}$ \\
\hline-8 & -0.0024 & $-3.18^{* * *}$ & -0.0018 & $-2.39^{* *}$ \\
\hline-7 & -0.0026 & $-3.48^{* * *}$ & -0.0020 & $-2.66^{* * *}$ \\
\hline-6 & -0.0033 & $-4.17^{* * *}$ & -0.0029 & $-3.56^{* * *}$ \\
\hline-5 & -0.0022 & $-2.76^{* * *}$ & -0.0018 & $-2.20^{* * *}$ \\
\hline-4 & -0.0033 & $-4.41^{* * *}$ & -0.0026 & $-3.43^{* * *}$ \\
\hline-3 & -0.0013 & -1.52 & -0.0007 & -0.84 \\
\hline-2 & -0.0013 & -1.51 & -0.0006 & -0.73 \\
\hline-1 & -0.0010 & -1.08 & -0.0007 & -0.75 \\
\hline 0 & -0.0027 & $-3.16^{* * *}$ & -0.0021 & $-2.46^{* *}$ \\
\hline 1 & -0.0020 & $-2.17^{* *}$ & -0.0014 & -1.54 \\
\hline 2 & 0.0000 & 0.02 & 0.0006 & 0.63 \\
\hline 3 & 0.0003 & 0.34 & 0.0006 & 0.65 \\
\hline 4 & -0.0003 & -0.32 & 0.0002 & 0.24 \\
\hline 5 & 0.0003 & 0.41 & 0.0011 & 1.38 \\
\hline
\end{tabular}

\section{5. 결론}

본 연구는 전환사채가 가장 활발하게 발행된 2015년부터 2018년까지의 4년을 연구기간으로 설정하고, 전환사채발행 1,421 건을 기본 연구표본으로 구성하여 전환사채 공시효과를 분석한다. 그리고 1,421 건을 발행한 529 개 기업을 대상으로 전환가액조정공시 1,798 건의 표본을 구성하고 
The Announcement Effects of Convertible Bond Issuances and Refixing Conversion Prices

전환가액조정(리픽싱)의 공시효과도 함께 분석한다. 본 연구에서 분석하는 표본은 최근 4 년 동안 국내에서 사모로 발행된 전환사채이며 리픽싱옵션의 채택비율이 $95 \%$ 로 매우 높은 특성을 갖는다. 리픽싱조항의 경우 가장 보편적인 조건은 리픽싱이 최초 전환가격의 $70 \%$ 까지 허용되고 매 3 개월마다 리픽싱을 하는 것이다(참고로, 액면가까지 허용되는 경우는 $29 \%$ 이고, 매1개월마다 리픽싱이 이루어지는 경우는 $30 \%$ 임). 본 연구는 전환사채발행 공시효과와 전환가액조정 공시효과를 중심으로 세 가지 가설을 도출하고 이를 검증한다.

$\mathrm{H1a}(\mathrm{b})$ : 전환사채발행 공시효과는 양으로(음으로) 유의적이다.

$\mathrm{H} 2$ : 리픽싱옵션이 포함된 전환사채발행의 공시효과가 리픽싱옵션이 포함되지 않은 전환사채 발행의 공시효과보다 작다.

$\mathrm{H} 3$ : 리픽싱조항이 포함된 전환사채의 경우 전환가격이 하향조정되는 “전환가액조정”의 공시효과가 음(-)이다.

본 연구의 주요 결과를 요약하면 다음과 같으며 위의 $\mathrm{H1a}, \mathrm{H} 2, \mathrm{H} 3$ 을 지지한다. 첫째, 전환사채 발행 공시효과는 양 $(+)$ 으로 유의적이다. 가장 큰 주가변화는 공시일 전일에 발생하는데 초과 수익률은 $2.87 \%$ 이고 $\mathrm{t}$-value는 14.50 이다. 공시일의 초과수익률은 $1.22 \%$ 이고 $\mathrm{t}$-value는 6.26 이다. 공시일 전에 $\mathrm{CB}$ 발행 정보가 노출된 것으로 판단되며, 공시일을 전후하여 3 일, 5 일, 7일간의 CAR가 각각 4.66\%, 5.83\%, 6.30\%이다. 양의 공시효과는 모니터링가설(Green, 1984; Shleifer and Vishny, 1986; Wruck, 1989)과 보증가설(Hertzel and Smith, 1993)에 의해 설명된다.

둘째, 자금조달 목적으로 구분하여 분석한 결과, 시설자금목적으로 전환사채를 발행하면 공시효과는 전혀 유의적이지 않고, 이는 운영자금목적 또는 타법인증권취득자금목적의 공시효과 보다 유의적으로 작다.

셋째, 리픽싱옵션이 포함된 경우의 공시효과가 리픽싱옵션이 포함되지 않은 경우의 공시효과 보다 유의적으로 작은데, 이는 리픽싱옵션에 대한 부정적인 견해를 반영한다.

넷째, 리픽싱옵션이 포함되면 공시효과가 유의적으로 작다는 세 번째 결과와 일관성있게, 전환가액조정 공시효과도 음(-)으로 유의적이다. 공시일에 초과수익률은 $-0.27 \%$ 이고 t-value는 -3.16이다. 시장이 전환가액조정 공시에 대해 부정적으로 반응하는 것은 투자자에게 지나치게 유리한 리픽싱옵션으로 인해 전환가격이 하향조정되는 것이 기존주주의 부를 해친다는 견해를 반영하는 것이다.

본 연구는 공헌도는 다음과 같다. 첫째, 전환사채와 신주인수권부사채에서 활발하게 이용되고 있는 리픽싱옵션과 관련하여 이의 부정적인 효과를 지지하는 실증결과를 최초로 제시한 점이다. 즉, 리픽싱옵션이 포함된 전환사채의 공시효과가 리픽싱옵션이 제외된 전환사채의 공시효과보다 유의적으로 작음을 보고하는데 이는 리픽싱옵션의 존재가 결국 공시효과를 하락시키는 부정적인 요소임을 의미한다. 또한 이 결과와 일관성 있게, 발행기업이 리픽싱옵션에 의해 전환가액이 하향조정된다고 공시하면 주가가 유의적으로 하락한다는 결과도 최초로 보고한다. 
한국증권학회지 제49권 2호 (2020)

요약하면, 리픽싱옵션은 주요 선진국에서 많이 이용되고 있지 않은 조항으로 투자자에게 지나치게 유리한 조항이지만 우리나라에서는 전환사채와 신주인수권부사채에 매우 활발하게 이용되고 있다. 이 조항은 전환사채와 신주인수권부사채의 발행을 용이하게 하지만, 사채의 이익구조를 변형하여 투자자와 주주간의 이해상충을 야기할 뿐만 아니라 사모로 발행되는 경우 최대주주가 악용할 여지가 많은 등 주주에게 매우 불리한 조항이다. Yoon(2019)은 사모 분리형 $\mathrm{BW}$ 의 경우 최대주주 등이 신주인수권을 행사하여 실현한 수익률이 평균 $1,441 \%$ 이며 이중에서 $674 \%$ 포인트가 리픽싱옵션으로 인한 효과라고 주장한다. 결론적으로, 리픽싱옵션에 대한 여러 부정적인 실증 결과는 리픽싱옵션의 혜택을 줄이거나 또는 제도를 수정해야 함을 시사한다. 
The Announcement Effects of Convertible Bond Issuances and Refixing Conversion Prices

\section{References}

Abhyankar, A., and A. Dunning, 1999, Wealth Effects of Convertible Bond and Convertible Preference Share Issues: An Empirical Analysis of the UK Market, Journal of Banking and Finance, Vol. 23, pp. 1043-1065.

Brennan, M., and E. Schwartz, 1988, The Case for Convertibles, Journal of Applied Corporate Finance, Vol. 1, pp. 55-64.

Byun, J., and K. Park, 2017, The Effect of the Refixing Option in Convertible Bond on Shareholders' Wealth, Conference Paper, pp. 485-509.

Duca, E., M. Dutordoir, C. Veld, and P. Verwijmeren, 2012, Why are Convertible Bond Announcements Associated with Increasingly Negative Issuer Stock Returns? An Arbitrage-based Explanation, Journal of Banking and Finance, Vol. 36, pp. 2884-2899.

Dwyer, A., T. Lechner, and Y. Zhang, 2018, An Investigation of Death Spiral Convertible Bonds, Working Paper, Tennessee State University.

Eckbo, B. E., 1986, Valuation Effects of Corporate Debt Offerings, Journal of Financial economics, Vol. 15 (1-2), pp. 119-151.

Eom, Y., and B. Cho, 2017, The Impact of Convertible Bond Arbitrage on Korean Stock Market Liquidity, Korean Journal of Financial Management, Vol. 34 (3), pp. 125-160.

Green, R. C., 1984, Investment Incentives, Debt, and Warrants, Journal of Financial Economics, Vol. 13, pp. 115-136.

Hertzel, M., and R. L. Smith, 1993, Market Discounts and Shareholder Gains for Placing Equity Privately, Journal of Finance, Vol. 48, pp. 459-485.

Hillion, P., and T. Vermaelen, 2004, Death Spiral Convertibles, Journal of Financial Economics, Vol. 71, pp. 381-415.

Hoffer, D., 2010, Is the SEC Stuck in a Misguided War against PIPE Financing?, The Tennessee Journal of Business Law, Vol. 12, pp. 10-36.

Jinn, T., 2011, A Study on the Valuation Effect of Private Placements of Bond with Warrant, Korean Journal of Financial Engineering, Vol. 10 (3), pp. 73-90.

Jung, M., and M. Cha, 2009, Convertible Debt Issuance and A Firm's Growth, Korean Journal of Financial Management, Vol. 26 (3), pp. 1-29.

Kang, D., 2016, Study on the Refixing Provisions and Anti-dilution Provisions, Law Review (Pusan National University), Vol. 57 (4), pp. 255-282.

Kang, J., and J. Baek, 2003, The Study on the Efficiency of the Financing Decision in Korea: The Effect of Private Equity Issues on Firm Value, Korean Journal of Finance, Vol. 16 (1), pp. 69-113. 
한국증권학회지 제49권 2호 (2020)

Kang, J., and R. Stulz, 1996, How Different is Japanese Corporate Finance? An Investigation of the Information Content of New Security Issues, Review of Financial Studies, Vol. 9 (1), pp. 109-139.

Kho, B., and R. Park, 2000, An Empirical Analysis on the Abnormal Performance of Security-Issuing Firms in Korea, Korean Journal of Financial Studies, Vol. 27, pp. 439-476.

Kim, J., 2001, About the Illegality of Refixing Option, ERRI Report, pp. 1-10.

Kim, H. J., and S. H. Han, 2019, Convertible Bond Announcement Returns, Capital Expenditures, and Investment Opportunities: Evidence from Korea, Pacific-Basin Finance Journal, Vol. 53, pp. 331-348.

Kim, C., S. Park, and S. Son, 1997, Does Issuance of Private Convertible Bonds and Bonds with Warrant Hurt Shareholders Interest?, Finance Forum, Vol. 2, pp. 8-11.

Kwak, Y., 2012, An Empirical Analysis of Convertible Bond Issues: Focused on Characteristics of Convertible Bonds and Issuing Firms, Korean International Accounting Review, Vol. 41, pp. 525-548.

Kwon, Y., J. Kim, and H. Choe, 1992, An Analysis of the Relationship between the Stock Market and the Convertible Bond Market in Korea, Korean Journal of Financial Studies, Vol. 14, pp. 485-522.

Lee, S., 2009, The Study on the Conversion Price of Convertible Bond, Law Review (Yonsei University), Vol. 19 (3), pp. 313-334.

Lewis, C., R. Rogalski, and J. Steward, 2003, Industry Conditions, Growth Opportunities and Market Reaction to Convertible Debt Financing Decisions, Journal of Banking and Finance, Vol. 27, pp. 153-181.

Lim, B., S. Lee, and P. Yoon, 2019, The Announcement Effect of Private Placements of Seasoned Equity Offerings, Korean Journal of Financial Management, Vol. 36 (1), pp. 151-178. Loncarski, I., J. Horst, and C. Veld, 2006, Why Do Companies Issue Convertible Bonds? A Review of Theory and Empirical Evidence, Advances in Corporate Finance and Asset Pricing, L. D. R. Renneboog (ed.) Elsevier, Amsterdam.

Mayers, D., 1998, Why Firms Issue Convetible Bonds: The Matching of Financial and Real Investment Options, Journal of Financial Economics, Vol. 47, pp. 83-102.

McConnell, J., and C. Muscarella, 1985, Corporate Capital Expenditure Decisions and the Market Value of the Firm, Journal of Financial Economics, Vol. 14, pp. 399-422.

Oh, S., and W. S. Kim, 2013, Different Motives and Different Market Reactions to Convertible Bonds and Bonds with Warrants Issuance in Korea, Working Paper.

Park, J., and J. Baek, 2003, Corporate Governance of Shareholder Wealth Maximization: An Analysis of Convertible Bond Issues, Korean Journal of Financial Management, Vol. 30 (2), pp. 1-39. 
The Announcement Effects of Convertible Bond Issuances and Refixing Conversion Prices

Shleifer, A., and R. Vishny, 1986, Large Shareholders and Corporate Control, Journal of Political Economy, Vol. 94, pp. 461-488.

Solidarity for Economic Reform, 2010, Expedient Bond with Warrant Issue Cases, Economic Reform Issue, pp. 1-13.

Stein, J., 1992, Convertible Bonds as Backdoor Equity Financing, Journal of Financial Economics, Vol. 32, pp. 3-21.

Woo, C., 1995, An Empirical Study on Market Reaction According to Announcement of Issuance of Convertible Bonds, Korean Journal of Financial Management, Vol. 12 (1), pp. 93-108.

Wruck, K. H., 1989, Equity Ownership Concentration and Firm Value: Evidence from Private Equity Financings, Journal of Financial Economics, Vol. 23, pp. 3-27.

Yoon, P., 2015a, Problems with Privately-placed Detachable Warrant Bonds Issuance System in Korea, Korean Journal of Financial Studies, Vol. 44 (1), pp. 25-51.

Yoon, P., 2015b, The Short-term and Long-term Wealth Effects of Privately-placed Detachable Bond with Warrant Issuances, Korean Journal of Financial Studies, Vol. 44 (3), pp. 517-546.

Yoon, P., 2016, The Announcement Effect of Seasoned Equity Offerings: A Re-examination, Korean Journal of Financial Studies, Vol. 45 (2), pp. 379-415.

Yoon, P., S. Choi, and B. Lim, 2017, Is it Advantageous for Managers to Announce Bad News Outside Trading Hours?, Korean Journal of Financial Management, Vol. 34(3), pp. 33-59.

Yoon, P., 2019, Refixing Option and Privately-placed BW Warrant Returns, Korean Journal of Financial Studies, Vol. 48 (2), pp. 129-155.

Yun, Y., and Y. Jeong, 2001, Studies on the Incentives of Issuing the Convertible Bond: Concerning on Common Stock Converting CB of Manufacturing Firms, Korean Management Review, Vol. 30 (1), pp. 27-45. 